

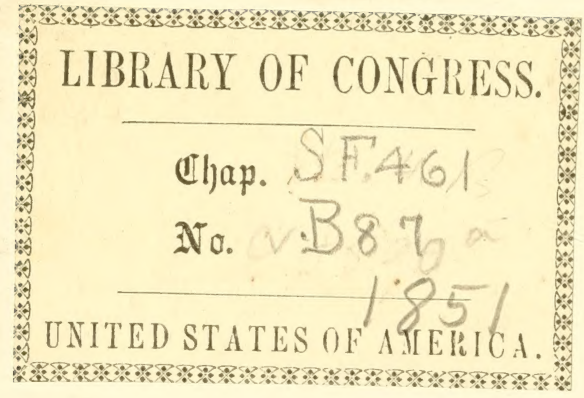




$-2$

SN 2 


\title{
THE
}

\section{AMERICAN BIRD FANCIER;}

CONSIDERED WITH

REFERENCE TO THE BREEDING, REARING, FEEDING, MANAGEMENT, AND PECULIARITIES

OF

\section{CAGE AID HOUSE BIRDS;}

\author{
WITH REMARKS ON THEIR
}

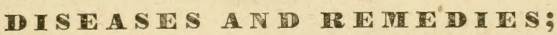

DRAWN FROM AUTHENTIC SOURCES AND PERSONAL OBSERVATION.

$$
\text { B Y D. J B R O W N E, }
$$

AUTHOR OF THE SYLVA AMERICANA, THE AMERICAN POULTRY YARD, ETC., ETC.

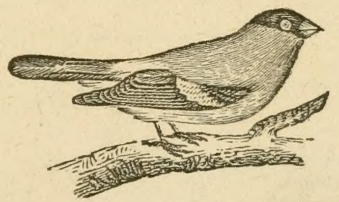

Illustrated with Engravings.

\section{New Work:}

PUBLISHED BY C. M. SAXTON. M. D C C C. L. 


\section{SF 461 \\ . B 87}

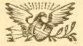

Entered according to Act of Congress, in the year 1850, by CHARLES M. SAXTON,

In the Clerk's Office of the District Court of the United States for the Southern District of New York.

Turney \& Bro.'s Stereotype.

16 Spruce St., New York. 


\section{IN DEX.}

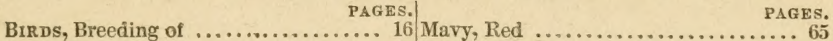

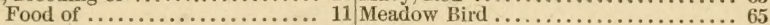

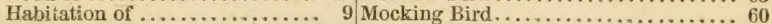

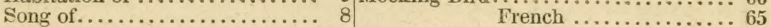

Young of, Time for Removing Pigeon, Barb................... 94

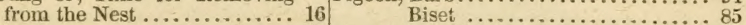

Blackbird, European ............... 70 Broad or Fan-tailed Shaker.... 81

Skunk ................ $73 \quad$ Capuchin................ 93

Bob-o-link ...................... 73 Carrier...................... 88

Bunting, Rice................. 73 Dragoon $\ldots \ldots \ldots \ldots \ldots \ldots \ldots . .62$

Butter Bird ...................... $73 \quad$ Helmet....................... 96

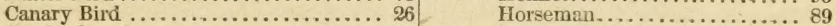

Cat Bird.................... Jacobin, or Jack $67 \ldots \ldots \ldots .92$

Diseases of Tame Birds....16, 39, 50, 59, 72 Mawmet, or Mahomet.......... 93

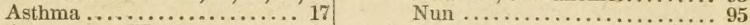

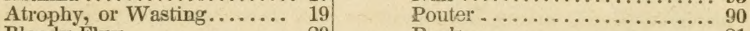

Bloody Flux.............. $2_{20} \quad$ Rock...................... 81

Consumption............... 19 Tumblers ................... 86

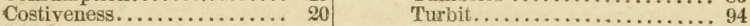

Diarrhœa................ 20 White-rumped................ 81

Epilepsy ................ 21 Quail, European ................ 104

Moulting ................ 23 Raven ........................ 77

Obstruction of the Rump Gland 21 Red Pole ......................... 46

of the Feet .............. 22 Reed Bird ...................... 73

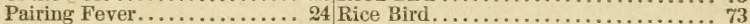

Parasitic Vermin........... 4 Bunting....................... 73

Pip, or Thrush............. 17 Troopial .................... 73

Rheum ................ 17 Robin, American .................. 54

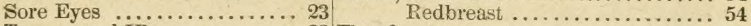

Tumors and Ulcers ......... 23 Thrasher ....................... 65

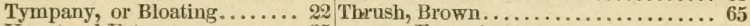

Unnatural Fatness .......... 25 Ferruginous...................65

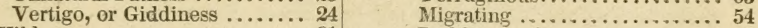

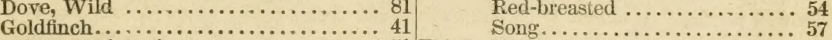

American .............. 51 Thistle Fineh ................... 41

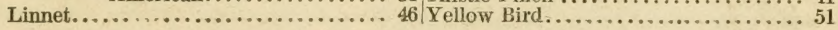

\section{ILLUSTRATIONS.}

PAGES. Pärie PAGES.

Aviary

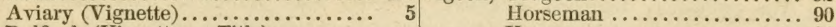

Bulfinch (Vignette on Title).

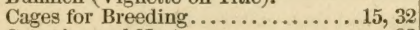

Houses ................. 98

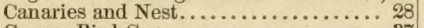

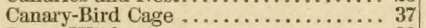

Dove, Wild....................... 82

Goldfinch . . . . . . . . . . . . . 43

Linnet. ..................... 47

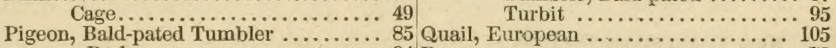

Jacobin, or Jack ............ 93

Pouter....................... 90

Ring (Vignette) ........... 81

Rock....................... 82

Shaker, Broad-tailed........ 85

Tumbler, Bald-pated ........ 87

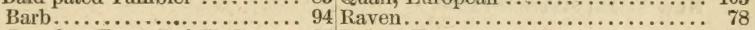

Broad or Fan-tailed Shaker... 85 Robin, European................ 55

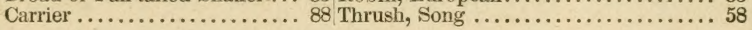


$\mathrm{N}$ issuing the present little treatise, the publisher would say a word respecting its charaeter and the manner in which it has been composed. He is fully aware of the limited nature of the work, when compared with the boundless science of which it forms a part, and would have ebeerfully extended the subject had he believed the wants and economy of the American public required it. To those who wish further to pursue the subject, he would recommend the more elaborate treatises of Audubon, Wilson, Bonaparte, Nuttall, and Dekay, for Aneriean birds, and particularly the works of Dr. Bechstein for the birds of Europe.

An intimate knowledge of Natural History, being an enthusiastic lover of the feathered tribes, having been familiar with them from his earliest ehildhood, has well qualified Mr. Browne for writing this, and if necessary, an extensixe work. He will doubtless be recolleeted by many as the editor of "The Naturalist," a monthly periodical, published in Boston some twenty years ago, and more recently as the author of the "American Poultry Yard" and of a treatise on American trees Within the above-named period, he has travelled and resided for a considerable time in various parts of North and South America, the West Indies, Europe, and Western Africa, (having passed several months-at the Canary Islands, for the express purpose of investigating, among other objects, the natural features of those countries, where he had ample opportunities for studying the habits of birds both in a state of nature, and in confinement, the most advantageous means of procuring them, and the proper mode of feeding and maintaining them in health.

In order that the author may not be accused of the reproach of wearing "borrowed plumes," it is hereby candidly confessed that he has made a free use of the writings of Audubon, Nuttall, and particularly those of Dr. Bechstein, as well as of the "Boy's Treasury of Sports," without giving them, in numerous instances, such credit as the punctilious critic would seem to demand. Be this as it may, the author has endeavored not to deviate from established eustor, except in cases where he deemed it expedient to change the language, in part, for the sake of brevity, elueidation, or Americanising the subject, or adapting it to our climate, economy, and social condition. Much of the matter, however, and several of the illustrations, he claims to be original.

The publisher, therefore, confidently presents the "Ameriean Bird Fancier" to the public with the full belief that it containes such information on the subject, as the taste and economy of our fais country women and their children require.

New YoRK; March 20, 1850. 


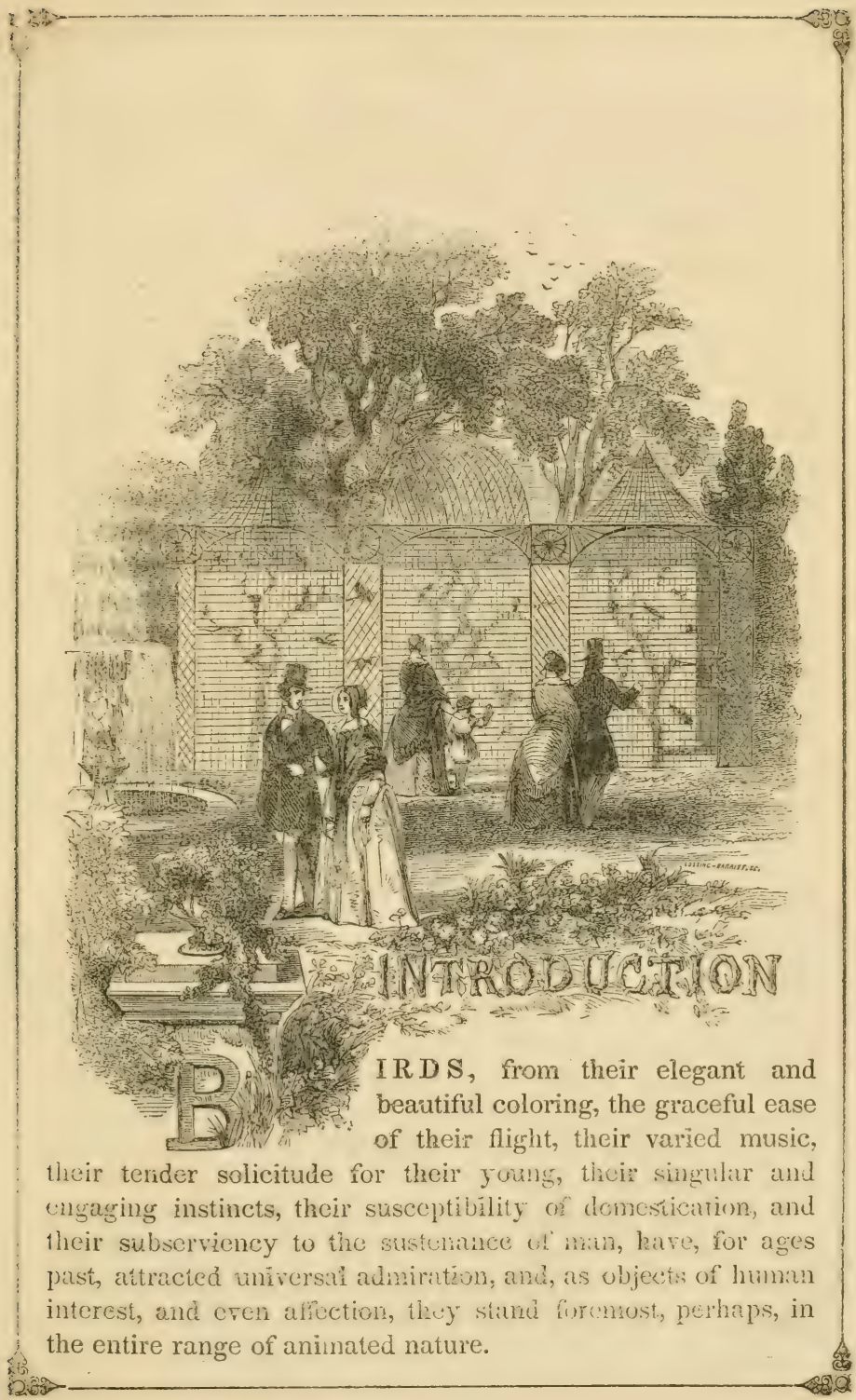


The structure of birds ard their habits of life, are wonderfully adapted to the varions functions they are destined to perform. The pointed beak, the long and pliant neck, the gently-swelling shoulder, the expansive wings, the tapering tail, the light and bony feet, aro all wisely calculated to assist and accelerate their motion through the yielding air. Every part of their frame is formed for lightness and buoyancy; their bodies are covered with a soft and delicate plumage, so disposed as to protect them fiom the intense cold of the atmosphere through which they pass; their wings are made of the lightest materials, and yet, the force with which they strike the air is so great, as to impel their bodies forward with astonishing rapidity, while the tail serves as a rudder to direct them to the different objects of their pursuit.

The internal structure of birds is no less wisely adapted to the same purposes. Their lungs have several openings, communicating with corresponding air bags, or cells, which fill the whole cavity of the body from $t\}$ ? neck downwards, and into which the air passes and re-pas es, in the process of breathing. This is not all ; their very bones are bollowed out with the design of receiving air from the lungs, from which air pipes are conveyed to the most solid parts of the body, and even into the quills and plumelets of the feathers which are hollow or spongy for its reeption. As all these hollow parts, as weli as the eclls, are only open on the side communicating with the lungs, the bird requires only to take in a fill breath to fill and distend its whole body with air, which, in consequence of the considerable heat of its body, is rendered much lighter than the air of the atmosphere. By forcing this air out of the body again, the weight becomes so much increased, that birds of a large size can dart down from great heights in the air with astonishing rapidity.

'This almost universal diffusion of air in the bodics of birds is of infinite use to them, not only in these long and laborious fights, but likewise in prerenting their respiration from being stopped or interrupted by the rapidity of their motion through a resisting medium. Were it possible for man to move with 
the swiftness of a swallow, the actual resistance of the air, as he is not provided with internal reservoirs similar to those of birds, would soon suffocate him.

The digestive organs of birds form them into two distinct natural classes; those with cartilaginous stomachs, covered with very strong muscles, called a gizzard; and those with membranous stomachs more resembling those of carnivorous quadrupeds. The former is given to birds, the principal food of which is grain and seeds of various kinds, or other hard substances that require much friction to divide, or comminute, to assist which, gravel is necessary; the latter is given to birds which feed upon flesh or fish, and whose digestion is accelerated more by the gastric juice than by the action of the stomach. Those of the first class digest or retain every substance swallowed; and those which eject or disgorge innutritious matter unavoidably taken in, such as feathers, fur, bones, \&c., belong to the second class, as is conspicuous in those that feed on fish. Graminivorous birds seem to possess the power of retaining the small stones taken into the gizzard, or evacuating them, when they become polished and less useful, but cannot disgorge them. In a state of nature, the quantity of gravel taken in, must be regulated, no doubt, by the sensation of the stomach; but, wonderful as it may seem, in domesticated animals, those instinctive faculties are deranged. Instances frequeatly occur where the whole cavity of the gizzard is filled with gravel stones. The food of graminivorous birds is conveyed entire into the first stomach, or craw, where it undergoes a partial dilution by a liquor secreted from the glands, and spread over its surface. It is then received into another species of stomach, where it is still further diluted, after which it is transmitted into the gizzard, or true stomach, consisting of two very strong musiles, externally covered with a tendinous substance, and lined with a thick membrane of prodigious power and strength, in which organ the food is completely triturated, and prepared for the operation of the gastric juices.

Graminivorous birds partake much of the nature and dispo- 
sition of herbivorous quadrupeds, agreeing with them in the number of their stomachs, the quality of their food, and the gentleness of their mammers. Content with the seeds of plants, with fruits, insects, and worms, their principal attention is directed to procuring food, hatching and rearing their offspring, and eluding the snares of men and the attacks of predaceous animals. The stomachs of cirnivorous birds are smaller than those of the graminivorous hinds, and their intestines are much shorter. Nany species of birds possess a reservoir for food, called a cranv, or crop, which seems to answer the same purpose as the first stonach of ruminating animals. Here it is that the from is softened and prepared for the stomach, or carried to the young.

THE SONG OF BIRDS.

Tre song of birds is always, if not the expression of love, at least that of pleasure. Thus, the uightingale sings only as Iong as pairing time or hatching lasts, and is silent as soon as

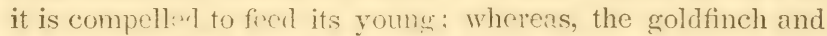
Canary sing throughout the year, and only cease when moulting dejects them. 'The continutition of the song of these birds, however, by no meanis proves that it is not occasioned by the stimulus of love.

Song appears to be the espe inl privilege of the male, whereby it either attracts the female or seeks to obtain her love; for there are but few females which produce notes similar to the song of the male, and these almost exclusively in a state of widowhood. They listen attentively, in fact, to the greater or less perfection or charm of the song of the male, to bestow upon that one their love whom they esteem the most accomplished singer. Thus, the most sprightly hen Canary sclects the best singer; and the chaffinch, when at liberty, will choose from among a hundred males the one whose song best pleases her. 


\section{HABITATION OF CAGE OR CHAMBER BIRDS.}

BIRDS which are kept only on account of their beauty, or for their animation and vivacity, are generally kept best in a room where they can run or fly freely about, and where they can resort at night for repose, to a large cage of many compartments, or to one or more fir trees. But larger birds should have an apartment expressly appropriated to them, as their frees smell umpleasantly in a dwelling room, whence also they require constant cleaning. Siniller birds may be allowed to run freely about, having a snall tree or a cage hung up for them to roost in. With this degree of liberty, many birds sing better than when confined in a cage.

Cleanliness is in every respect very important in keeping birds, for they are not only thereby preserved for many years but it keeps them constantly healthy and cheerful; hence it is necessary that the cage should be clcaned at least once a-wcek, and birds which run about upon the ground, should have the sand renewed frequently; the perches also of such as use them should be carefully cleaned. If this be not attended to, the birds will become sickly, and will suffer from lame feet, gout, and other maladies, terminating in the loss of their toes, as all must have experienced who have been accustomed to keep birds, and have neglected cleansing them. In cleaning their feet, it is very requisite that the bird should have them dipped in water before the dirt is removed; for if this be not done, the skin, to which the dirt closely adheres, comes off with it, which renders the bird not merely lame, but also attracts to the part all the unhealthy humors generated by their unnatural mode of living.

It is in the feet indeed that cage or chamber birds chicfly suffer, and they must be daily examined to see that nothing gets entangled about them, as hair thus twisted will frequently cut very deep, and in the course of a few days, that portion of the foot or toe, so tied up, will dry up and fall off. Very great 
attention must be pạid to this particular circumstance, as scarcely a bird can be preserved for any length of time with all its toes uninjured. It is not to be denied, however, that many birds keep themsclves exceedingly neat, whilst others, even of the same genus, are so uncleanly, that they are not only always soiling themselves, but never clean their feet, beak, nor wings.

Some bird fanciers take delight in making birds so tame as to be taken upon the hand into the open air, or to be allowed to fly away and come back again upon a call. "One of iny friends," says Dr. Bechstein, "who has tamed birds as well as otters, adders, foxes, weasels, and martins, so that they would follow him upon a sign given, adopts the following easy and certain method to effect it:-When he wishes to accustom a bird to fly abroad, or to go out with him perched upon his finger or his shoulder, he first teases it with a soft feather in its cage which stands open. 'The bird soon snaps at the feather, and then at his finger, and it will then come out of the cage, and perch upon the extended fingrer; he immediately strokes it, and lays a few choice morsels uefore it. These, the bird will soon take out of the hand its : $i$. Ho then commences by familiarising the bird with son peculiar call or whistle, and he carries it, as soon as it permits itself 10 brasped in the hand, placed upon his hand or shoulder, from chamber to chamber, taking care to close the doors and windows; he then suffers it to fly, and calls it back again. As soon as it attends to this call without being seared or frightened, he takes it cautiously into the open air, and shus the bird becomes gradually so accustomed to him that he can carry it abroad or into company without its offering to fly away."

Care, however, must be taken not to carry adult birds, which have been thus tamed, into the open air whers they can hear their fellows, in the spring or at pairing time, which are us:ually the periods when they show indications of resuming their native wildness.

If it is wished to teach a bird to eat out of the mouth, it nust be kept for a time in the cage without fool, and then 
when sitting upon the fingry its firyorite lived must be held to it upon the tip of the calcded fongue. Inuger soon teaches it to peck. Such tame birds learn, cilwo, speedily to sing upon the finger. To accomplish this, nothing more is necessary than to induce it by cortain tones, motions, and fondling. But it is still further requisite to observe in this process of taming, that, to be effectral, it sliould be continued for a longer time than is here laid down. May we not presume that the bird will, in the course of a few wecks, do that frecly which has been taught, or rather forced upon it, in this short space of time.

\section{FOOD OF TAME BIRDS.}

In selecting the food of birds in confincment, it is requisite to do so, as fir as is practicalsle, in accorlanec with the nature of its foed in a naturol sture. This, indect, is frequently difficult, if not wholly imposible. Great cultion, therefore, must be observed te aecusion the hirds we harpl or yather their ste - echs, by degreces, to the food we are compelled to supply treni, although it camot be denied that there are birds, also, which, as soun as they are placed in the aviary, eat anything that is given to then. But others are nure delicate, and will we: cia at all, partly from griof at the loss of their liberty, and partly from not finding the food they have been accustomed to. Great care must therefore, be taken of these. If such as are known to be delicute-the majority of singing birds-for instance, connence grerilily eating as soon as they are placed is the chamber, it is a bad sign; for they will certainly dice as it implies an unuatual indifference to the loss of their liberty, which is almost always deducible from sickliness. Those which crecp into corners and scem for some hours to pine, it is less nccessary to be anxious about; but they must not be disturbed until their ill-humor subsides.

Dr. Neyer, of Ofenbich, Germany, rmarts as follows upon 
"this subject:- "An almost unfuiling" mode of accustoming' binhs to their food, which is known to be extremely difficult in many, is thus: Let the bird be placed in a cage in the room where it is purposed to be kept; give it freely appropriate food and drink in open vessels; leave it thus undisturbed for several hours; then catch it and dip it in fresh water, and again place it in its former cage. It will now sit for some moments tharoughly exhausted, but will soon recover and begin preening itself, and in the course of a few minutes become extreinely animated, and then it will certainly eat the food put befure it. Doubtless the siune cause produces an appetite in birds after bathing as in man."

In order to give some general rules for the best food of cage or house birds, I have divided then, after Dr. Bechstein, into four following classes:-

The first comprihends those birds which live only on secds, such as Canaries, goldfinches, Siskins, \&c.

The second are these which feed both on seeds and insects, such as quails, larks, cat birds, and mocking birds; some of these also eat the buds and berries of trees.

The third are those which seck only berries and insects, such as nightingales, redbreasts, thrushes, and the like.

The fourth are those which ent insects only, such as wagtails, woodpeckers, cuckoos, \&̊c.

The birds in the last-naned class are the most difficult to preserve; but most of them, having nothing particular in their song, ofier but little compusation for the trouble and care which they require.

Recipe for a General Foon.- - In proportion to the number of lirds, white bread enough must be baked to list for three montins. When it is well baked and stale, it must be put again into the oven, and left there until cold. It is then fit to be pounded wn mortar, and will keep sereral months without becoming baci. Erery day a teaspoonful for each bird is taken of this meal, on which is poured three timess as much colll, or lukewarm, (but not boilng,) milk. If the meal be good, a firm f facto will be fomed, which nust be chopped rery sianll on a 
board. This paste, which is very nourishing, may be kept a long time without becoming sour oi sticky; on the coms "ary, it is always dry and brittle. As soon as a delicate bir ${ }^{7}$ is brought in, some flies or chopped worms should be mixed wit ${ }^{{ }^{1}}{ }^{7}$ the paste, which will attract it to eat. It will soon be accustomed to this food, which will keep it in life and health.

Although the notice of a universal remedy is generally suspicious, the two following sorts of paste have been recomminded, and used with success, agrecing well with all, or nearly al, tamed birds, if we except those which are confined in cages on acconnt of their beautiful songs. They are not only very simple and cheap, but also prevent great loss of time to tiose who possess a great mumber of birds.

Universal Paste.-To make the first paste, take a white loaf which is well baked and stale; put it into fresh water, and leave it there until quite sonked throngh; then squecze out the water and pour boiled milk over the loat, adiling about two thirds the quantity of barley meul with the brin! well sifted out, or, what is still better, wheat meal.

For the second paste, grate a carrot very nicely (this ro.nt may be kept nearly a whole year if buried in sand); then soak a small white loaf in fresh water, press the water out, and put it and the grated carrot into an earthen pan; add two harilfuls of barley or wheat meal, and mix the whole well together with a pestle.

These pastes sliould be made fresh every morning, as they soon become sour, particularly the first, and consequently hurtful.

Every molning, fresh water must be given to the birds, both for drinking and bathing. When a great many are left at liberty, one dish will do for them all, about eight inches long, and two in width and depih, divided into several partitions, by which means they are provented fromi plunging entirely into the water, and in consequence making the place always dirty and damp. A vessel of the same size and shape will do for holding the universal paste, but then it must have no partitions. 
Those birds which devour everything thrown to them, must be protected against the possibility of having any food given to then that contains pepper or much salt, and especially ngainst putrid meat. This is a universal rule of precaution. It may further be observed, that to birds confined in cages, 110 more must be given than they can eat during the day; otherwise they will accustom themselves to scatter their food oit of the vessel, and eat the best first, leaving the worst for subsequent fare; and are consequently to-day well, and drooping to-morrow.

\section{BREEDING.}

There is but little to be seid of the breeding of brids in confinment, as, in the majority of ceses, it is dingentt to aceomplish, excepting as as can be thoroughly familiarised, like Canaries. Of . fling nlaces, there are two kinds, one a large cage made of wire or wood, and the other the entire range of a room. Both should be dry, airy, and exposed in our northern climate to the warmth and light of the sun. It is (-hichy requisite to supply birds that are to breed with a still, solitary, and speicious abodo; and it is preferible to give them an entire apartment in which erererens are placed that have not lost their leaves. Above all things, it is desirable to make this abote as nearly rescinble their natural dwelling place as possible, that they may be excited to pair. With crery care, however, to render their breeding place like the natural one, it is difficult to supply them with the necessary materials for their nests. This defieiency should be supplied by nests artificially formed of woren cotton, willow, straw, or turned wood, into which they will only have to convey appropriate linings; for this purpose, the $y$ must be supplied with the hair of animals and raw silk, cotton, wool, \&c.

Especial care must be taken to furnish the birds with requisite food, which partly contributes to fit old ones for breeding, and which must also be suited to the varying 


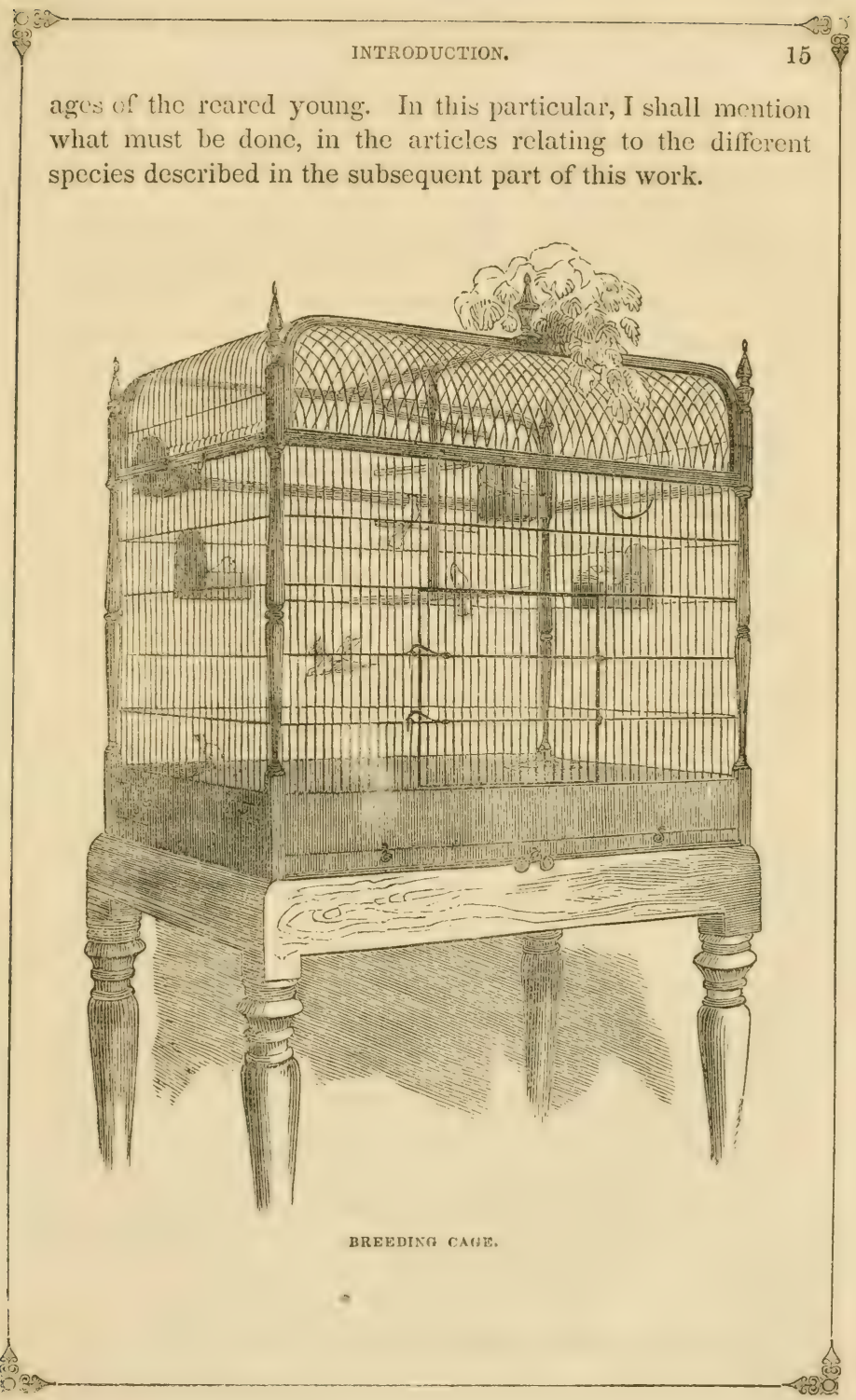




\section{IIME FOR REMOVING WILD EIRDS FROM THE NEST.}

IT may be necessary that I should give some general directions about the time at which it is desirable to remove young wild birds, intended to be reared, from the nest. 'This is when the tail quills shoot forth, and when all the feather's begin to expand, and before the birds can yet completely open their eyes. If they are removed earlier, their stomachs are too weak to endure the food of the aviary, and if it take plice later, it is usually extremely difhicult to induce them to open their beaks to receive food with which they are unacquainted. But there are species of birds which can at all times be easily fed and tamed. As à general rule, all seed-eating birds may be ta med, both adult and young.

\section{DISEASES OF TAIVIE BIRDS.}

LIKE all tame snimals, birds that are kept in confinement, are e posed to mor" maladies than those which live at large: * and esircially as they are frecuenily so closely confined in cages that hey have scarty room to move. These maladies, howeycr; are considerably irereased by their having all kinds of dolicacics as pastry, sugur, we., giten them, which spoil their stomachs and usually prodace a slow constmption.

The follow ing ate the chief malastes which affect birds, and their remedies, as lait. down by Dr. Bechstein, the efficiency of which he proved upon his own. Indect, the variety of birds, as well as the variety of hroir food, requífses also a difference of treatment in their maladies; and in speaking of each species, I sioll have occasion to notice how their peculiar diseases may be trested, when tive general rurelies are not suitable to their nature.

* It has been flei, iently asserteri that biris in tireir natural state are never ill, but this is unfounded. 
PIP, or Thrush.-This is a catarrh, or cold, by which the nostrils are stopped up, and the membrane covering the tongue is hardened by inflammation. In large birds, it is common to remove this skin, taking it off from the base to the tip; but rough modes should not be used for doing it. A little borax, dissolved in water, may be applied to the tongue with a camelhair pencil two or three times a-day until a healthy action is produced. By this means, this part can again perspire, the saliva necessary for digestion can flow, and the taste and appetite return. A mixture of fresh butter, pepper, and garlic, gencrally cures this catarrh. It is a good thing, also, for the birds to drink the pectoral infusion of speedwell (Veronica officinalis); and the nostrils may be opened by passing up a small feather dipped in oil. The ruflling of the head, the beak often open and yellow at its base, and the tongue dry, are the most decisive indications of this disease.

Rreur.-The symptoms "this diswse are frequent sneezing and shaking of the head. Some drop of pectoral elixir in the infusion of speedwell, which the sick birds must be made to take, appears to be the most efficacious remedy.

When it is merely hoarseness, Dr. Handel, of Mentz, in France, gave to his birds for several days, as their only drink, a very dilute decuction of dry figs, sweetencel with a little sugar, and afterwards purged them, for two days following, with the juice of carrots.

Asthua.-This is a very common disease among house birds. 'Those attacked with it have their breath short, often open their beaks as if to gasp for more air, and, when agitated or frightened, keep them open for a long time.

The cause of this discase may doubtless be found in the mode of life which the birds lead. Their food is generally too dry and heating, being principally hemp seed, which is very injurious, but liked by all; and is the more hurtful, as it inclines them to cat too much. If to this, be added the unchanged air of the rooms, particularly those which have stoves instead of chimneys, and the great heat which is kept up 
during winter, it is plain that there is much to injure the delicate lungs of the birds.

A moist and refreshing regimen and some aperients, more or less often, according to the violence of the discase, appears the most appropriate remedy. A favorite linnet and goldfinch, mentioned by Dr. Bechstein, when attacked with rery bad asthma, were relieved and preserved for several years by the following method:-

The first thing was to leave off hemp seed cntirely, confining them solely to rape seed; but giving them at the same time an abundance of bread, soaked in pure water, and then pressed; lettuce, endive, or water cresses, according to the season, twice a-week, giving them bread boiled in milk, about the size of a nutmeg. This is made by throwing a piece of the crumb of white bread, about the size of a nut, into a teacupful of milk, boiling it, and stirring it all the time with a wooden spoon till it is of the consistency of pap. It must be quite cold before it is given to the birds, and must always be made fresh, for if sour, it will prove injurious.

This paste, which they are very fond of, purges them sufficiently, and sensibly relieves them. In very violent attacks, nothing but this paste ought to be given for two or three days following, and this will soon give the desired relief.

When the disease is slight, or only begun, it is sufficient to give the bread and milk once in three or four days. When employed under similir circumstances, this treatment has cured several very valuable birds. It may not be useless here to renew the advice of always giving the birds an opportunity of bathing every day, by putting in their way a saucer, or any other small shallow bath, filled with water, which should never be too cold, and in winter always milkwarm.

One thing which is very injurious to the lungs of birds, and which too often occurs, is the fright occasioned by tormenting them, or by scizing them too suddenly; for the poor little things often rupture a blood vessel in the breast while beating themselves about. A drop of blood in the beak is the sign, and 
a speedy death is the general consequence. If this do not happen, the breathing is not the less difficult and painful; and recovery is rare, at least without the greatest care and attention.

Birds that eat insects and worms, occasionally, by accident, swallow some extraneous substance, which, sticking in their throat, stops their respiration and stifles them. The only remedy is to extract the foreign body, which requires much skill and dexterity.

When asthma is brought on by cating seeds, which are too old, spoiled, or rancid, Dr. Handel recommends some drops of oxymel, (honey and vinegar boiled to a syrup,) to be swallowed for eight days following. But the best way is to change the seed, and be sure there is none but good seed in the feeding trough.

Atrophy, or WAsting.-This is caused by giving unnatural food to the bird, which destroys the digestive power of its stomach. In this case, it disgorges its food, rufles its feathers, and does not arrange them, and becomes thin very fast. The best thing is to make it swallow a common spider, which purges it, and put a rusty nail into its water, which strengthens the tone of the stomach, giving it at the same time its proper and natural food. Green food, such as lettuce, endive, chickweed, and particularly water cresses, is the safest remedy. A rery great appetite is a sign of this disease. A Siskin, mentioned by Dr. Bechstein, that was dying of atrophy, had nothing but water cresses for three days following, and on the fourth he sung.

Consumption.-This is usually the result of unnatural food, which interrupts the function of digestion, and it is recognised by the bird inflating and distending its lf. The feathers are ruffled, and the flesh dwindles. No better remedy, perhaps, can be found than to give such birds a common spider, which purges them, and to lay in their water a rusty nail, which strengthens the stomach. They must, at the same time, be fod with the best description of their appropriate food. In birds which will eat vegetables, and especially water cresses, this 
will be found the surest remedy against consumption, or waste. Usually, birds suffering from this malady have a voracious appetite for green food. Dr. Bechstein fed a Siskin, which had already completely wasted, for three successive days, with nothing but water cresses, and on the fourth it recommenced singing.

Costrveness.-This diserse may be discovered from the frequent unsuccessful end avors of the bird to relieve itself: Aperients will be of usi. It a spiler does not produce the desired effect, anoint the rint of the bird with the head of a pin steeped in linseed oil; this surt of clyster generally succecds. Boiled bread and mille is also of great service.

Drarrnes.-This is a discase to which birds that have been caught recently are very subjest, Defore they are accustomed to their new food. Nost of these die of it ; they continually void a white calcareous matter, which sticks to the feathers round the vent, and being very acrid causes inflammation in that part and in the intestines. Sometimes chalybeate water, (iron water,) and the oil clyster produce good effects; but it is better, if possible, to procure for the bird its most natural food. Some people pull out the feather's from the tail and vent, and then rub these parts with fresh butter, but this is a very painful and cruel operation. They also mix the yolk of an egre boiled very hard with their food, but this does not succecl very well. If there be any hope of curing this disease, it is by attacking it at the beginning, before inflammation is violent; boiled bread and milk, a plenty of lettuce, or any other similar green refreshing food, generally effects a cure.

In a case of chronic diarrhoe, which almost reduces the birds to skeletons, Dr. Handel, of France, prescribes chalybeate water, mixed with a little milk for their drink, which, he: says, is an easy and certain cure.

Bloody Flux.-This is a disease with which some partots are attacked. The best remedy is to make the birds drink a plenty of boiled milk, or even very fat broth; for their intestines, which are very much irrituted, requirc something soothing to protect them from the acrid discharges, which, at the 
same time, must by corrected be healing food. Birds in this state, generally do nothing but drink; therefore plenty of boiled milk should be given them, as it nourishes them, as well as acts medicinally, but should it appear to turn sour in the stomach, it must, at least for some time, be discontinued.

Obstruction of the Rump Gland.-This gland, which is on the rump, and contains the oil employed for anointing the feathers, sometimes becomes hard and inflamed, and an abscess forms there. In this case, the bird often pierces it itself, or it may be softened by applying fresh butter without any salt; $\mathrm{bc}$ it is better to use an ointment made of white lead, litharge, wax, and olive oil, which may be had of any good chemist or apothecary. The general method is to pierce or cut the hardened gland, in order to let out the matter.

The gland is known to be obstructed when the feathers, which surround it, are ruffled, the bird never ceasing to peck them, and instead of heing yellow it becomes brown. Dr. Bechstein says, this discase is very rare among wild birds, for, being exposed to damp, and bathing often, they make more use of the liquor in the gland, consequently, it does not accumulate sufficiently to become corrupted, sour, or cancerous. This confirms the necessity of giving them the ineans of bathing as often as instinct would induce them, as nothing can be more favorable to their health.

Dr. Handel, after piercing the gland, recommends a little magnesia to be mixed with the bird's drink.

EpILEPsy.-This is a discase with which house birds are very often attacked. What has been found to be most useful in this case, is to plunge the sick birds every now and then into very cold water, letting them full suddenly into it, and cutting their claws, or at least one or two, short enough for the blood to run.

From bleeding giving so much relief, one would think that this disease is a kind of apoplexy, occasioned by want of exercise and too much food. Bullfinches and thrushes are more subject to it than any other birds, and bleeding always cures them, which has been done with great success in the fol- 
lowing mainer, but much delicacy and shill are required, as there would be great danger of laming the bird:-A very small hole is made on the surface of the claw, with a lancet or very sharp penknife; it is then plunged in lukewarm water, and if the operation be well done, the blool runs like a thread of red silk; when removed from the water, the bieeding stops; no bandage nor dressing is required.

Tympant, on Blonting.-In this disorder, the skin on one part of the body, or even the whole body, rises and swells to so great a degree that it is stretched like a drum. It is generally sufficient to pieree it with a pin, so as to let the air escape, and the bird will be cured.

Disease in the Feet.-House birds are often subject to bad feet. From the second year, they become pale, and lose their freshness. They must be frequently cleaned, taking care to remove the skin; the thick loose scales ought also to be taken off, but with all possible precaution.

The gout occasions the feet to swell; they are also so scaly and painful that the poor little bird cammot support itself without resting on the points of its wings. Di. Handel presicribes a warm fomentation with a decoction of sorpunt (sepratria offecinalis). If a fout should he bruised or broken, ho advises that the discased bird should be shut up in a rery sina!l cage, the bottom of which i: rery smooth and eron, withest any perches, or anything which would tempt it to hon, and put in a very quict and solitary place, out of the way of anything which might produce agitation. In this mamner, the bird will cure itself in a little time, without any bandage or plaster of any kind.

Di: Bechstrin was of the opinion that the principal cause of bad fect is want of bathing. The scales, contracting from dryness, occasion great pain; in order to remove them with case, and without danger, the fect must be softened in lukewarm water. 'The following method has been used with a bullfinch with success:-Its cage was made with a movable tin bottom, which, being half or three quarters of an inch deep, could hold water, that was put in tepid, to bathe the bird; 
the perches were then removed, so that the bird was obliged to remain in the water, where it was left for half an hour, sometimes throwing it hemp seed to amuse it. After repeating the bath once or twice, the bird became very fond of it; and it was remarked that its feet became, if we may say so, quite young again. The scales being sufficiently softened, the middle of each was cut lengthwise without reaching the flesh; this made the sides easily fall off. It is better to remove only two scales a-day, that the bird may not be wearied. By continuing the bath three times a-week, the feet become healthy and supple, and the bird is easy.

Sore Eyes.-The juice of red beet for drink, and also as a liniment, greatly relieves this disorder. Dr. Handel, of Mentz, recommends washing the eyes, when disposed to blindness, with an infusion of the root of white hellebore.

Tumors and Ulcers.-As to the tumors and ulcers which come on the heads of the birds, Dr. Handel touches them with a middling-sized red-hot lnitting incedle. This makes the watery humor run out, and the wound afterwards dries and heals. To soften the pain, a little liquid black soap is used. If, from the softness of the tumor, matter seems to have formed, it should be rubbed with fresh butter until it is come to a head; it may then be emptied, and opened by a few drops of essence of myrrh. During all this time, the bird must have nothing but beet juice to drink.

Ulcers in the palate and throat may be cured by making the bird drink the milk of almonds for several days, at the same time lightly touching the ulcer's several times a-day with a feather dipped in a mixture of honey and borax.

Moulting.-This occurrence, though natural, is generally accompanied with disease, during which the birds ought to be taken great care of. 'Their food should be changed, but without giving any heating delicacies, which are very injurious.

It has been observed that birds always moult at the time when their food is most abundant; the forest birds may then be seen approaching fields and cultivated places, where, having plenty of insects and seeds, they cannot suffer from want; 
indeed, the loss of their feathers prevents their taking long flights, and the reproduction of them occasions a loss of flesh which must be repaired. An abundance of food is therefore necessary, and, following this rule, during moulting, some additional food must be given to house birds, appropriate to the different species-millet or Canary sced, a little hemp seed, white bread soaked in water, and lettuce, or endive, to those which feed on seeds; with a few more worms and ants' eggs to those that eat insects; all should have bread soaked in boiled milk, warmth, and baths. Nothing has succeeded better than this regimen.

Vertigo, on Giddiness.-This, without being properly a disease, is rather common, and is occasioned by the trick which the birds of the first class have, of turning their head and neck so far round that they fall off their perch. They may be easily cured of this trick by throwing a covering over the top of the cage, which prevents their seeing anything above them, for it is with looking up that this giddiness comes on.

Pairing Fever,-A disease which may he called the "pairing fever" must not be forgotten here. House birds are usually attacked with it in the spring, or at the time when the inclination to pair is erreatest. They cease to $\sin 2$, become sorrowful and thin, rufle their feathers, and die. 'This fever generally first seizes those which are contined in cages; it appears to arise from their mode of life, which is too uniform and wearying. They may be cured merely by placing them in the window, where they are soon so much refieshed that they forget their grief, their desire for liberty, or for pairing, and resume their liveliness and song.

It has been observed that a ingle female in the room is sufficient to cause this disease to all the males of the same family, though of different species. Removing the firmale will cure them directly. The males and females, at this season, must be separated, so that they cannot see nor hear one another. This, perhaps, is the reason that a male, when put in the window, is soon cured.

Parasitic Vermin.--If birds are sometimes restless, especially 
of a night, and if they are observed to be frequently feeling with their beaks about the abdomen, back, or wings, they must be examined to see if no small yellow insects, (lice or mites,) may be discovered upon the body, or between the feathers. If this be the case, they must be sprinkled by means of a small syringe with water, in which quicksilver has been steeped, or with a much diluted infusion of tobacco, for several successive days, whereby these vermin are destroyed or chased away. Another mode of getting rid of the lice is to bathe the birds frequently, and to give them, daily, fresh or dry sand, and to be very particular in keeping them exceedingly clean.

Unnatural Fatness.-If it be found that the birds become unnaturally fat, which is often the case, especially during autumn, in some species of warblers, their too nutritious food must be changed and Swedish turnips, (ruta-bagas,) be mixed in it, and dry ants' eggs put into their drink, which much checks their corpulency.

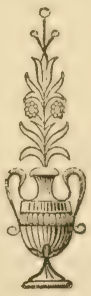




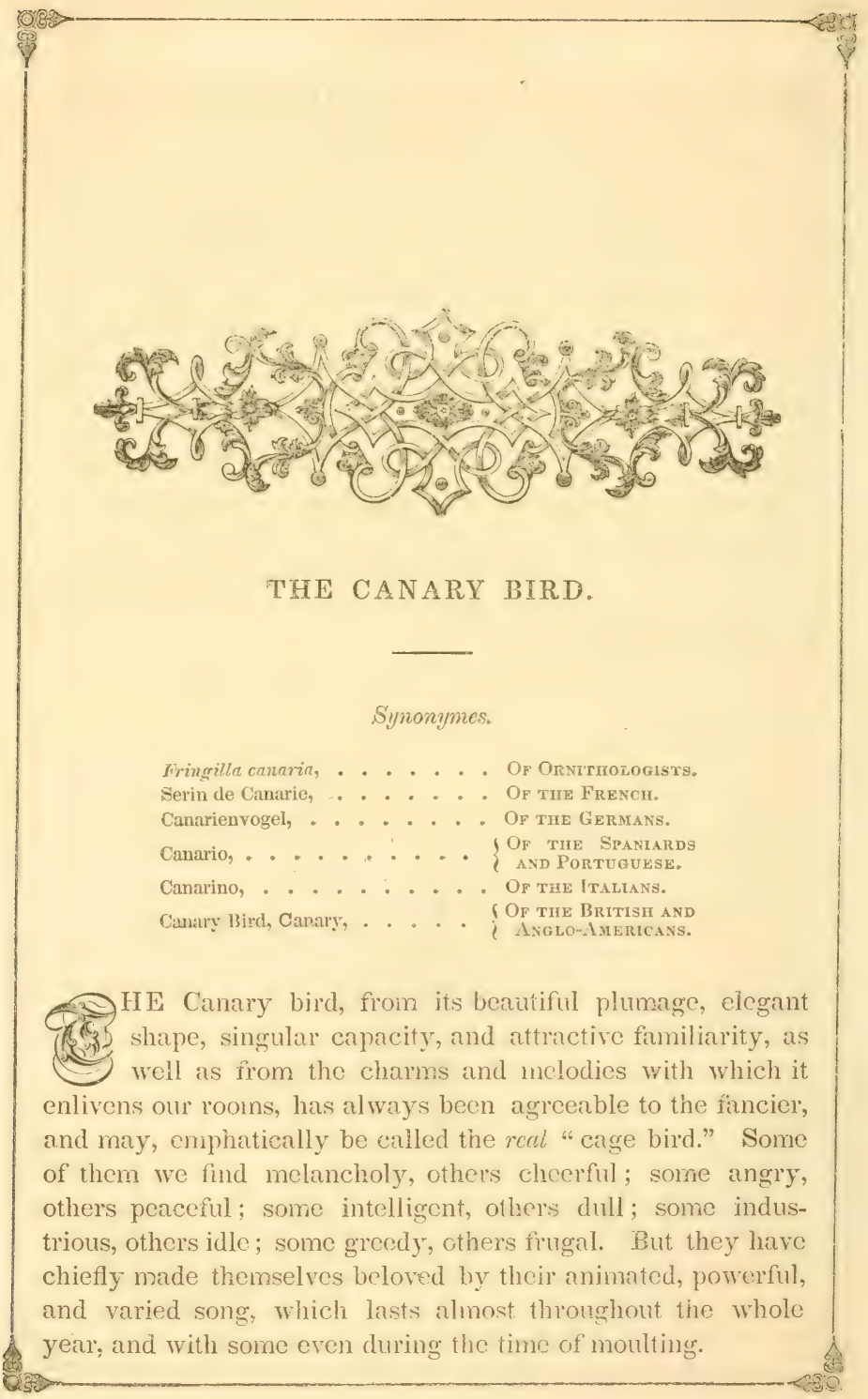


These birds are also distinguished by their correctness of ear, the remarkable skill they possess of imitating all tones, and their excellent memory. Not only do they imitate the notes of other birds, which they greatly improve by mixing them with their own, but they will even learn to utter short words with some degree of correctness. In their wild and undomesticated state, their song is unvaried, as with most other birds, less melodious; of fewer notes, and uttered at longer intervals than with us; at least, I found them so, as far as my observation extended, when a resident of the Canary Isles.

\section{ORIGIN AND FISTORY.}

Those birds, from which are descended the Canaries now liept and reared throughout the whole of Europe, and even in Russia and Siberia, as well as in various parts of North and South America, in an unalulterated state, are natives of the Canary Islands, where they breed in pleasant valleys, and on the delightful banks of small rills, or streams. 'They were known in Europe as long ago as the beginning of the sixteenth century, as we are told, concerning their arrival, that, "A ship, which, in addition to other merchandize, had a multitude of Canaries on board, that were consigned to Leghorn, was wrecked on the coast of Italy, and the birds, thereby obtaining their liberty, flew to the nearest land." This happened to be Elba, where they found so propitious a climate, that they multiplied without the intervention of man, and probably would have naturalised themselves, had not the wish to possess them been so great as to occasion thein to be hunted after until they were entirely extirpated. In Italy, therefore, we find the first tame Cinaries, where they are still raised in great numbers. At first, their rearing in Europe was attended with considerable difficulty, partly because the mode of treating these delicate strangers was not sufficiently understood, but principally because males, chicfly, and not fimales, were introduced. 


\section{DESCRIPTION.}

The Canary bird is five inches in length, of which the tail comprises two inches and a quarter; the beak is five lines long, stout, sharply pointed, and whitish; the legs are liesh-

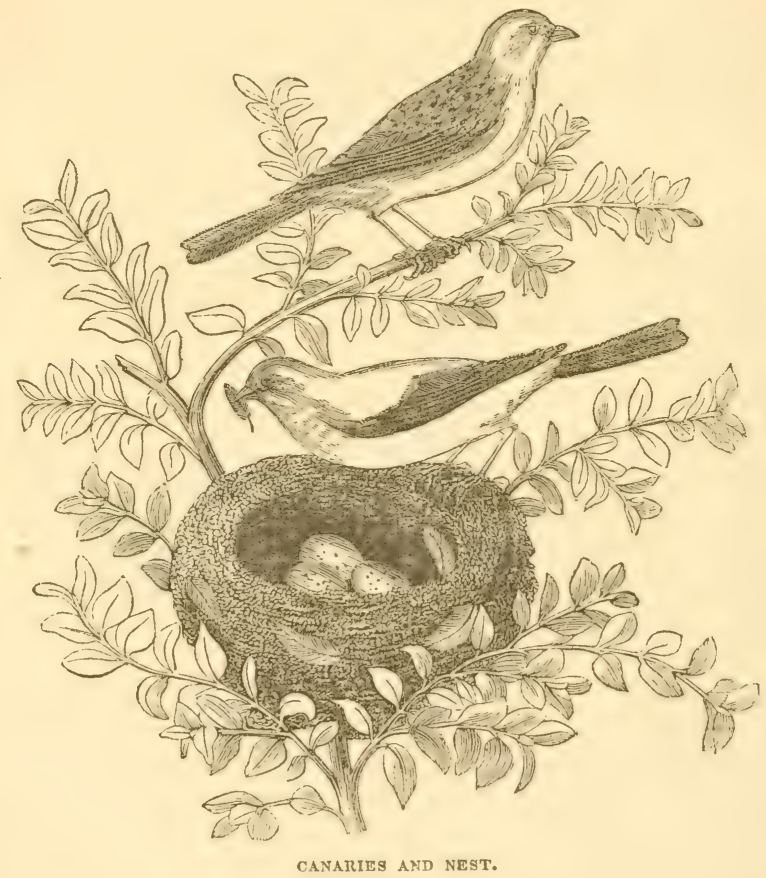

colored, and cight lines high. The female is scarcely to be distinguished from the male, but the latter has generally deeper and brighter colors; the head is rather thicker; the body, in i general, more slender throughout; and the temples and the 
space around the eyes, are always of a brighter yellow than the rest of the body.

The origrinal grey color of this bird, which merges into green bencath, has, by means of domestication, climate, and intermixture with other birds, become so multifarious, that Canaries may now be met with of almost every hue; but grey, yellow, white, blackish and reddish-brown, are the prevailing colors, which are individually seen in every degree of shade, or combination, and thus present innumerable differences. Those which are of a blackish-grey, or greyish-brown, above, with greenish-yellow bencath, like a greenfinch, are the most common, generally the stiongest, and approach the most closely to the original color of their primogenitors. The yellow and white ones have usually red eyes, but are more delicate. The chestnut-colored are the most rare, and in strength and length of life are intermediate. 'The colors of most Canaries consist of a mixture of these, and that bird is the most prized the more regularly it exhibits the combination of these various shades. That which is most generally admired, at present, is one with yellow, or white, upon the body, and of a dun-yellow color on the wings, head, and tail. Next in degree of beauty, is that which is of a golden yellow, with a black, blue, or blackishgrey head, and similar wings and tail. There are also blackish or grey ones, with yellow heads, or with a ring about the neck, white, with brown and black markings, ashy-grey, almost black, with a yellew breast, and white head and tail, all of which have a prominent value. Others, which are irregularly marked, and are variegated, or mottled, are less esteemed.

\section{HYBRIDITY.}

As remarked in a preceding page, the original color of the Canary bird is grey, which merges into green beneath, almost rescmbling the colors of the linnet; but by means of domestication, climate, and intermixture with other $t$ rds, as the citril finch and serin, of Italy, and with the Siskin and linnet, 
of Germany, they have become so multifarious, that they are to be met with of almost cvery color and hue. Furthermore, in Europe, there are societie's for promoting the breeds, and premiums are awared to competitors who come nearest to the model of perfection given out for competition. The hybrids produced by crossing the Canary with other birds, most in favor, may be described as follows :-

1. rhe Cross betucen the Canury and Goldfinch.-The colors of this variety consist of a very beautiful intermixture of those of both parents. One which has been highly prized, was mark! in the middle of the crest with ashy-grey; the rest of the head, and the upper part of the neck, was of a silvery white, with a bright orange-red ring round the base of the beak, and another ring of snowy whiteness round the neck; the back was grayish-brown, striped with black; the rump, white; the mader part of the boly, snow-white; the rent, the wings, and the first pinion fenthers, were also white; the rest, as well as the corerts, black, algel with yellow, and with a golden-yellow spot in the centre of the wings; the tail was white, with a black lateral spot; the heak and fect, white, the former with a black tip. The mother of this fine bird was white, with a greenish erest. In general, the handsomest varietice are produced when yellow or white Canaries are pared with goldfinches.

2. The Cross betwen the Canary and the Sistin.-This is perfertly like the fumale Siskin, if the male bird is a green Cantry, hut if the latter be white or yellow, it becomes rither brighter and always retains the color and figure of the Siskin.

3. The Cross belween the Canary and the Serin is distinguished only by its smaller size, and by its short, thick, beak, from the common grey or green Canary, unless produced by a white or yellow hen.

The Cross between the Canary and the Linnet.-When the orispring of a grey Canary, its only difference is a slightly Ionger titil: but it is rariegated or speckled when the Canary is yellow or white. 


\section{PAIRING AND L.AYING.}

Is order to obtain birds of a briliant plumage, it is requisitc to pair together such as are of similar markings, and the colors of which are regular and distinct. This is best effected in separate breding cases. Varicgated and checlicred ones are often produced in aviaries where the birds pair together indiscriminately. Those of a greenish and brownish color, paired with bright-yellow ones, often produce bcautiful dusky-white, or other firvorite colors. A requisite precaution to be observed is, that a tufted and a sinooth-headed bird should be piirer together; for, if two crested ones be placed with one another, a part of the head of their progeny will be bald, or otherwise deformed.

Some males are always dejected, sing but little, are indifferent to their mates, and consequently unfit for breeding; others are too choleric, incessantly snap at, and chase about, the females, and indeed, often kill them and their young; others, again, are teo arcent, persecute the female while she is sitting, tear the nest, throw out the eggs, or continually excite her to pair, until she quits her cggs or neglects her young; others, in breeding time, sing so incessantly, and so powerfully, that they rupture the small vessels of the lungs, and suddenly drop dead in the midst of their song.

The females have also their defects. Some merely lay, and immediately quit their eggs as soon as laid; other's feed their young badly, bite them, or pluck out their feathers; others lay with much exertion and labor, and when they should hatch become sickly, or lay ogain after a long interval.

Those birds which are to be paired for the first time, should be placed together in a small cage or an open room for a week or ten days, to be wonted to one another. If two females are to be paired with one male, they must previously be accustomed to each other's society by being also kept together in a small cage; and the breeding cage should have two A compartments, separated by a board, in which a sliding door 
has been made. In one compartment, a lively male may be enclosed with a female. About the cage or room, there should be placed some flax, soft hay, wool, hog's bristles, eow's hair, moss, picces of thread, cut about a finger's length, paper, shavings, or other dry materials for building the nest, which usually occupies three days. When one female has laid eggs, the sliding door may be moved and the male admitted to the other female; and when they have both laid, this door may be

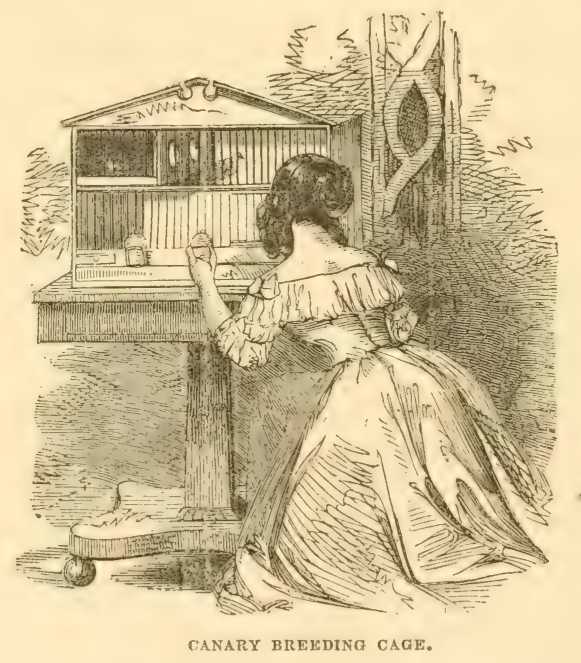

kept open. The male will visit both females alternately, when they will not trouble theinselves about each other; otherwise, without this precaution, jealousy would incite them to destroy each other's nests and throw out the eggs. In a room or aviary, a male has sometimes two and even three females placed with hin; with one of these, he will more especially pair. But when this firvorite is about to sit, the others will receive a share of his attentions, and from the latter usually s the greatest number and the best birds are reared. 
The female, as with the majority of birds, is usually the architect, the male only selecting the place and procuring materials, the coarser of which is used for the external structure, and the finer for lining the inside of the nest. The females will sometimes show indications of their instinct by building nests after their own fashion, generally being irregular in figure, and not nicely finished, at least externally. It is in the nest itself, where the pairing takes place, the female attracting the male by a continuous piping note, repeated more quickly the nearer she is to laying. An interval of seven or eight days elapses between the first pairing and laying the first egg. Every day afterwards, nearly at the same hour, an egg is laid, the number varying from two to six.

\section{BREEDING, INCUBATION, ETC.}

THE month of March is the best time to place the birds in the breeding cage. Of these, there are two linds, either a large one, made of wire, as is shown at page 15 , in which it is better to place a male, and one female, than one male and two females together, like the one shown in the preceding page; or the birds may have range of an entire room. All breeding places must be exposed to the warmth and light of the sun, and be hung about with nests made of turned wood, tin, or little wicker baskets, two for each pair.

When a room is allotted to the purpose, it ought to contain shrubs for the birds to perch or build upon, with a plenty of fresh water to drink and bathe in, that being indispensable for all birds. The light should be admitted into the east or southeast, for the benefit of the morning sum, and the windows should have wire cloth over them, that the birds may enjoy the fresh air. The floor of the apartment should be strewed with clean gravel or sand, on which should be thrown celery or chickweed; but when breeding; they should have nothing except hard-chopped eggs, dried roll, calie without salt, and once in two or three days a few poppy secds. 
Whon the birds are grood breeders, it is needless to attempt to assist nature by artificial means; and it is best to leave the them entirely to themselves. In other cases, it is customary to remore the first cges, and replace it by an ivory one, placing it in a bo: filled with clean, dry sind, and so taking avay all the erges till the bist one is laid; all are then returned to the nest to be hatched. 'Tley often lay three or four times a-year, firom Februty to Scptember, and some are so assiduous in pairing, that even moulting does not intermpt them. The reses ate of a scal-gireren color, marked on oise end with reddishbrown of vislet spots or stripes. The period of incubation lasts thirteen days.

If, from the sicliline'ss of the male, or of the female, any of the exgs are unimpresnated, they must be taken out of the nest when the hen has sit for a week or ten days, held lightly between the fingers in the sumshin, or in a loright light; the fecundated ones will then appear filled with reins, while the bad ones will be quite clear, or already addled, the latter of which must be thrown away. The male rarely relieves the fomale in hatching, nor disws she very willingly permit it. Inmodiately after feeding, she retimns to the egers, and should the male ferehance be on the nest at the time, if he should not directly quit, he would sperelily be compelled to do so by pecks and blows. The young are occasionally killed in the cyge, in consequence of lond and near moises, such as heavy thunder, the discharge of fire arms, violently slamming the door, or any other very loud knocking.

\section{FEEDING AND REARING THE YOUNG.}

As sonn as the youmg are hatehed, the old birds should be supplied with one fourth of a hard-boiled $\mathrm{egg}$, minced very fine, with some dried roll, or bread, containing no salt, steeped in water, the latter of which should be squeczed or pressed out amain. In another ressel, some boiled rape sued should be plited, which has locen rewashed in fresh 
water, to take arvay the acidity. Some use crackers instead of bread, but this is mmecessary. It is merely requisite to see that this soft food does not become sour, otherwise it will kill the young, and the cause remain unsuspected. Some persons mercly give them their ustual food, intermixing it with some fincly-powdered crackers and hard-boiled eggrs, but it has been found by experience, that the diet prescribed above is more eflicacious, especially until the young are fledged.

It is now that the male takes the chicf part in rearing the young; and upon him devolves the duty of feeding them, in order to allow the female to recover firm the cxhaustion she has received from incubation.

If it is necessary to feed the young by hand, grated roll or pulverised dry crackers is taken, inixed with pounded rape seed, and kept in a box. As often as it is necessary to feed them, a little of it is moistened with some of the yolk of an egg and water, and given to them from a quill pen. This must be done ten or twelve times a-day; about four penfuls is the quantity necessary for each meal.

Up to the twelfth day, the young remain almost naked, and require to be covered by the female; but after the thirteenth, they will feed themselves. In cold, dry years, however, it sometimes happens that the birds get scarcely any plumage at all. When they are a month old, they may be removed from the breeding cage. With the usual food of the old birds, they must be fed for some time upon the kinds above named; for, the sudden removal from soft food often occasions death, especially in moulting. It is asserted, and not without reason, that those Canaries which are reared in an arbor, where they have space to fly about within an cnclosure of wire, are longer-lived and stronger than those which are reared in a chamber or a confined cage.

It is a curious fact, perhaps not known to every one, that, when there are two females with one male in a cage, and one dies, the other, if she has not already sat, will hatch the eggs laid by her co-rnate, and rear the young as her own; and, during this foster-mother care, cautiously avoid the caresses of the male! 
TO TEACH A YOUNG CANARY TO SING.

When the young birds can eat alone, say at the age of thirteen or fourteen days, and often befor'c quitting the nest, the males commence warbling, and the females, also, but less connectedly and from this, the sexes may be distingnished. To teach a young Canary to sing, he must now be separated from his comaudes, as well as from other birds, and placed in a small wire cage, which, at the commencenent, must be covered with linen, and strbsequently, by degres, with thicker woollen cloth, when a short air, or other musical piece, must be whistled to him, or a flute, or a small organ inay be used. This lesson should be repeated five or six times a-day, especially mornings and evenings, and in five or six months, he will be able to arcquire the air, according to the power of his memory.

\section{FOOD AND MANAGEMENT OF ADULT BIRDS.}

Except during the breeding season, the males may be kept in cages either bell-shaped or like that denoted in the adjoining cut. 'These may be made of wire or rattan, and should be at least a foot high and cight inches in diameter, with one or more transverse perches.

The female is allowed cither to have freedom in the room with her wings clipped, or is placed in a large breeding cage, possessing sufficient space to keep her limbs in constiant exercise, and preserve them in health and strength.

In the bell-shaped, or smaller cages, wherein it must be understood only one male should be put, both the eating and drinking vessels must be placed on the outside, at the extremities of the lower perch. These should be surrounded by a cap of tin, so that the bird may not easily scatter its food. Cleanliness will ofien prevent these delicate songsters from suffering many disorders, and it is very desirable that the 
floor of the cage should be male movable, that it may be more easily cleansed and strewed with coarse sand.

Being naturally inhabitants of it wimm climate, and rendered delicate by constant residence in rooms, and so, in a manner habituated to a temperature similar to that of their own country, great care is necessary in winter, in order that the same or a similar temperature may be preserved, avoiding the exposure to cold air, which, however, refreshes in summer,

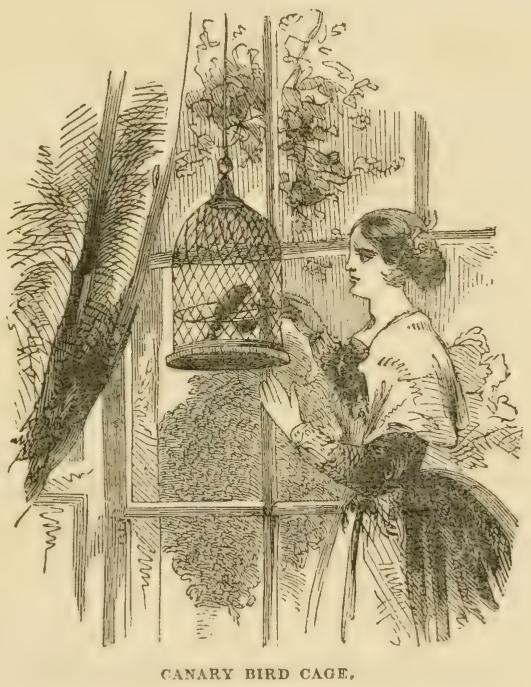

camnot be otherwise than prejudicial to them, causing sickness and even death. To keep these birds in a healthy and happy frame, it is very important to observe that, in summer, they be frequently hung in a cage in brilliant daylight, and if possible, placed in the warn sunshine, which, especially when bathing, is very agreeable to them.

The most imporiant consideration in the management of the male is his food. The more simple and true to nature 
this is, the better does it agree with him; whereas, when too artificially compounded, it renders him sickly and weak. The best food is the "summer rape seed," which is sown in spring. This is distingnished from the "winter rape seed," which is sown in autumu, by being larger and of a darker hue. On this diet, these birds thrive very well, but it should be occasionally intermixed with some crushed hemp seed and Canary seed, for the sake of flavoring it; and this more especially in the spring, when they are intended for breeding. As a treat, we may occasionally give them a mixture of summer cabbage seed, whole oats or oatmeal, with millet, or some Canary seed. Here, as in most other cases, we should strive to imitate nature.

The hen Canaries may likewise be supplied with the same kind of food as the males; but in winter, they are content with bread, containing no salt, or merely barley grots, moistened in milk, if given to them fresh every day, without being sour. Besides, both males and females may be given, in summer, some green lettuce, cabbage, groundsel, and water cresses, which must be previously washed and cleansed from anything prejudicial; and in winter, they maty be fed with pieces of sweet apples. They require fresh water daily, both for drinking and bathing; and at moulting time, a rusty nail should be occasionally placed in their drinking vessel, as this tends to strengthen the stomach.

\section{TO TEACH THE ADULT BIRDS TO FLY.}

Canaries may be taught to fly; but the trouble and risk are so great that it is hardly worth the time and care necessary to teach them. The male is first allowed its liberty in a place where there are trees, and the female is hung at a window, neav by, which speedily attracts him back to the cage in case of danger or fatigue. This teaching must be continued for five or six days, but no handling nor violent attempts to catch them should be used. 


\section{DISEASES.}

The Canary bird, in a state of captivity, seldom enjoying the open air and having but little exercise, is subject to most of the maladies peculiar to the domestic, feathered race. The diseases to which it is particularly liable, may be described and treated as follows:-

1. Rupure.-This is a common malady, especially in young birds, and is a kind of indigestion which causes intlammation of the intestines. The symptoms of this disease are a lean, transparent, blown-up body, full of small red veins, and in which all the intestines seern to have fallen to the lower part of the body, where they become entangled and turned black. Too much nutritious food is the cause of this evil. All remedies appear to have been ineffectual in this malady, but assistance is sometimes obtained from a spare and simple diet.

2. The Yellow Gall in the Head and Eyes may be cured by refreshing food; but if there be a tubercle of the size of a homp seed about the head or eyes, it must be cut off, and the wound anointed with fresh butter.

3. Sweating.-Some females, whilst hatching, have a sweating sickness, which is injurious to the blood, and may be detected by the feathers of the lower part of the body being quite wet. The body of the bird should be washed with brine, and afterwards with rain or spring water to free the feathers of salt, and then rapidly dried by the sun or fire. This may be repeated once or twice a-day. This sickness, however, is not so prejudicial to the bird as is generally supposed.

4. Sneezing.-This is occusioned by a stoppage of the nostrils, and may be removed by a very small feather dipped in olive oil being passed through them.

5. Loss of Voice.-If the male, after moulting, lose his voice, he must have diet similar to that given to young birds; that is, some thoroughly-baked, stale roll, dipped in boiled milk or water until completely saturated; then press out the milk and 
mix it with more or less, say a proportion of two thirds of coarse barley or wheat flour, freed from the husk or bran. Some persons give them a slice of pork or bacon to peck.

6. Constipation is cured by giving them plenty of green food, such as celery, water cresses, chickweed, sallad, \&c.

7. Epitepsy is commonly brought on by too great a delicacy of treatment, and also by timidity, from alarm. Too great an abundance of rich food, and the want of proper exercise, whercby much and thick blood is produced, are the chief causes of this disease. The birds ought to be kept fiee from alarin, either by catching or tormenting them in any way. When suffering under this complaint, if they are hot, it is recommended to dip them frequently into cold ice water, and then pair their nails so closely as to start blood. A few drops of olive oil, also, given internally have proved serviceable.

8. Otergrown Claus or Beaks require to be pared with sharp scissors. Care must be taken, however, not to cut the nails too close, as the birds would be liable to lose so much blood as to become lame. The end of the "rod ray," or vein, both in the beak and claws, when held up to the light, shows exactly how fir they may be cut. During the hatching period, also, the nails of the female sometimes must be cut, in order that they may not be caught by them when in the nest.

9. Lice may be avoided by frequent bathing, cleanliness in the cage, and dry sand mixed with anise seed and scattered on the floor. 


\section{THE GOLDFINCH.}

\section{Synonymes.}

\begin{tabular}{|c|c|}
\hline Fringilla carduelis, & OF ORNITHologists. \\
\hline Chardonneret, & Of the French. \\
\hline Distelfink, Stieglitz, & Of the Gerinans. \\
\hline Jilguero, & Of the Spaniards. \\
\hline Pintaçilgo, & Of the Portuguese. \\
\hline Calderino, & Of the Italians. \\
\hline Goldfinch, Thistle Finch, & $\left\{\begin{array}{l}\text { OF THE BRITISH AND } \\
\text { ANGLO-AMERICANS. }\end{array}\right.$ \\
\hline
\end{tabular}

F all cage birds, this is one of the most delightful,
$(3)$ alike from the beauty of its plumage and the excel-
lence of its song, its proved docility, and remarkable animation, whose body is almost always in incessant motionnow moving to the right and now to the left. Its song is shrill, agreeable, and heard during all seasons, excepting only at the period of moulting. It contains, besides many warbling and twittering notes, on which it dwells more or less, and the oftener the syllable fink is repeated the more it is admired. Some utter these notes only once or twice in their song, and others four or five times in succession. They also repeat airs, and the songs of other birds, but with difficulty; for they have not the same capacity as linnets and Canaries for these acquisitions.

Their docility is extraordinary, for they will even learn to fire small cannons and imitate death. They may also be taught to draw up their food and water in a little bucket. 
Mr. Syme, in his execllent treative on British Song Birds, gives the following anusing particulars respecting this species:- "The goldfinch is easily tamed and easily taught, and its capability of learning the notes of other birds is well known; but the tricks it may be taught to perform are truly astonishing. A few years ago, the Sicur Roman exhibited his birds, which were goldtinches, limnets, and Canuries. One appeared dead, and was held up by the tail or claws without exhibiting any signs of life; a sccond stood on its head with its claws in the air; a third imitated a Dutch milkmaid going to market with pails on its shoulders; a fourth minicked a Venetian girl looking out at a window; a fifth appeared as a soldier, and monnted gruard as a sentinel; and the sixth acted as cannoneer, with a cap on its head, a firelock on its shoulder, and a match in its claws, and discharged a small cannon. The same bird also acted as if it had been wounded. It was wheeled in a barrow, to convey it, as it were, to the hospital, after which it flew away before the company. 'The seventh turned a kind of windmill; and the last bird stood in the midst of some fireworks, which were discharged all round it, and this without exhibiting the least symptom of fear."

The Goldinch is very gencrally distributed throughout Europe, occurring in most of the wooded and cultivated districts. Its song commences about the end of March, and continues till July or August. It may often be found in company with limnets, whose flight it somewhat resembles.

\section{DESCRIPTION.}

THE goldfinch is five inches and three quarters long, of which the tail occupies two inches. The beak is five lines long, sharply pointed, and very slightly bent, compressed at the sides, whitish, with a horn-colored tip; the slender feet are brownish, and six lines high; the front of the head is of a A bright scarlet red; a broad margin of a similar color surrounds 
the base of the beak; the chin and reins, black; the vertex black, terminating in a stripe, which passes the back of the head, and descends the neck on each side; on the top of the neck, there is a white spot; the checks and front of the neck, white; the back of the neck and back are of a beautiful brown; the rump whitish, with a brownish tinge; the longer futhers are black; both sides of the breast and the flanks of a bright-brown; the middle of the breast, the belly, and the vent, whitish, many of the feathers having a brownish tinge; the thighs, greyish; the pinion feathers, velvet-black, with whitish tips, which are smallest in old birds, and are sometimes wanting in the first two feathers; the middle of the cxternal

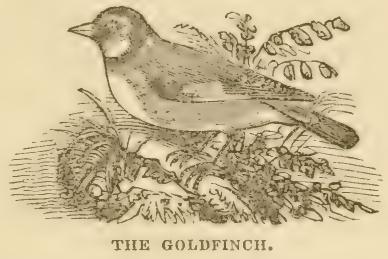

web with a golden-colored stripe an inch long, which, in conjunction with the golden yellow tips of the hinder large coverts, forms a beautiful spot; the coverts otherwise black; the tail slightly forked and black; the two, and sometimes the first three pinion feathers having a white spot in the centre of the inner web; the rest with white tips; sometimes also the third is likewise entirely black at the sides.

The female is a little smaller, not so broadly and beautifully red about the beak; the chin brownish; the cheeks intermixed with bright-brown; the small coverts of the wings, brown, and the back of a deeper dark-brown.

\section{BREEDING.}

The female goldfinch rarely lays more than once a-year, (consequently these birds do not greatly multiply, ) and then 
from four to six eggs, which upon a pale sea-green ground are marked with pale-red spots and dots, and deep-red stripes. The young are fed from the crop. These, before they first moult, are grey upon the head. They can be reared upon poppy seeds and roll steeped in milk or water. They have greater facility in imitating the song of the Canary than that of any other bird; and with this bird they will produce fertile hybrids. To effect this, a male goldfinch is placed with one or two hen Canaries, and they very readily pair, especially if the goldfinch has been reared from the nest. The birds which spring from this union are not only beautiful in color and plumage-often yellow, with the head, wings, and tail of the goldfinch-but they will be found to excel in the sweetness and variety of their song. If you are apprehensive that a pair of valuable Canaries will not thoroughly hatch their eggs, nor let their young ones die, lemove them to the nest of a goldfinch; they will not only hatch them, but will also feed the young, which, when nearly full fledged, may be placed in a cage until they can feed themselves, when no further trouble attends their rearing.

The characteristics which mark the principal varieties of this species are as follows:-

1. Goldfinch with a yellow breast.

2. The White-headed Goldfinch.

3. The Black-headed Goldfinch.

4. T'he White Goldfinch.

5. The Black Goldfinch.

The latter are either entirely black, which is caused by age or in being fed upon hemp seed, or they retain the yellow spots on the wings. Mr. Shelbach, of Cassel, in Germany, reared a nest of goldfinches, which he kept entirely secluded from the light of the sun, covering the cage with cloth. These birds were of a jet-black, with yellow spots, but they changed color atter moulting. Those goldfinches which become black before old age, usually resune their former color after moulting, but then they do not usually live much longer. 
FOOD.

THE goldfinch feeds up $\mathrm{n}$ various kinds of seeds, groundsel, succory, salad, cabbage, rape, linseed, Canary, thistle, and alder seeds, \&c. In the cage, it must be fed upon poppy seed and hemp seed, the first being given as its usual food. If allowed to run freely about, it will accustom itself to the second description of universal food described at page 13. It may also have given to it all sorts of green things, such as salad, cabbage, lettuce, and water cresses. It eats voraciously, and therefore, when allowed to run about in the chamber, perches upon the trough, and chases away, with a threatening gesture, every bird that approaches; whereas, it will feed with other birds that have any kind of resemblance to it, at least with respect to the character of their food, such as Canary birds, Siskins, \&c.

\section{DISEASES.}

THESE birds are very subject to epilepsy. If they happen to have bad and swollen eyes, they should be anointed with fresh butter. Heaviness and greediness, occasioned by feeding too cxclusively upon hemp seed, may be removed by giving them in lieu of it soaked salad and thistle secds. It contributes much to their health, if occasionally supplied with the head of a thistle.

In old age, they become blind, and lose the beautiful red and yellow colors of the head and wings. Although frequently subject to sickness, there are instances of their having lived to the age of sixteen and even twenty-four year's. 


\section{THE LINNET.}

\section{Synonymes.}

\author{
Fringilla cannabina, \\ Linot, \\ Hänfiing, Lanning, \\ Pardillo, \\ Pintarroxo, \\ Frnello, \\ Linnet, Brown Linnet, \\ Whin Linnet, Lintie,
Greater Red Pole,
}

Linnet,
Of Ornithologists.

Of the French.

OF THE GerMaNS.

Of the Spantards.

Of the Portuguese.

OF THE ItALIANS.

Of tile Britisir.

$\left\{\begin{array}{c}\text { OF THE ANGlo } \\ \text { AMERICANS. }\end{array}\right.$

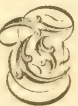

IIE limet, from its natural flute-like voice, excels most other song birds in its power of beautifully and purely initating melodies and airs which are piped to it, and for this quality it is especially estecmed. It will also learn. the song of all the birds in the room or cage that it hears. Its natural song eonsists of many connected strophies, and is the more beatutilu the oftence it utters som? high-sounding notes, which are called its "crowing." form its resemblance to the crowing of a cuck. It siness both summer and winter, excepting the time of moulting.

\section{DESCRIPTION.}

THE length of this bird is more than five inches, of which the tail measures two inches and a half. The beak, six lines long. 
point brown; the iris dark-brown; the feet, eight lines high, are black. There are some very striking varietics produced by the season and age in the plumage of the male, which are not observed in the female, and these have caused great confusion in works on birds.

A male three years old or less, is distinguished in spring by the following colors, and by the name of "red pole:"-The forchead is blood-red, the rest of the head reddish ash-colored, the top rather spotted with black; the cheek, sides of the neck, and the circle round the eyes, have a reddish-white tint; the feathers of the back are chestnut, with the edges lighter; the upper tail coverts are black, edged with reddish-white; the throat and under part of the neck are yellowish-white, with some dashes of reddish-grey; the sides of the breast are

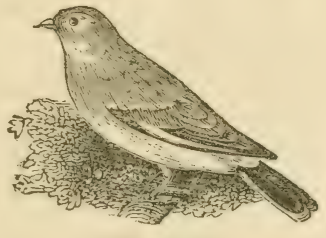

THE LINNET.

blood-red, edged with reduish-white; the sides of the belly are pale rust-colored; the rest of the under part of the body is reddish-white; the greater wing coverts are black, bordered with reddish-white; the others are rusty-brown with a lighter border. The quill feathers are black, tipped with white; the first are edged with white nearly to the point; the narrow beard forms a parallel white streak to the quill feathers; the tail is black and forked; the four outer feathers on both sides have a broad white border; that of the two middle feathers is narrower, and reddish-white.

After moulting, in autumn, little red is scen on the forchead, because the feathers become colored from the bottom to the top; the breast has not yet acquired its red tint, for the white border is still too wide; but when winter comes, its color's appear. 
Males one year old have no red on the head, and more dashes of black; the breast is pale-red, waved with pale and dark; the under part of the feathers on the breast is only a bright, reddish-grey brown; the edges of these feathers are of a reddish-white; the back rust-color, having detached spots of dark-brown and reddish-white. These birds are known under the name of "grey linnets."

After the second moulting, if the reddish-grey feathers are blown aside, blood-red specks may be discovered on the forchead, and the red of the breast is only hidden by the wide yellowish-white borders to the feathers; these are the "yellow linnets," or the "rock linnets," as they are called in Thuringia.

Besides these three different varictics of plumage of the males, there are several clouded, produced by the scasons and old age; for instance, the older they becoine, the redder the head is. Birds brought up in the house never acquire the fine red on the forchead and breast, but remain grey like the males of one year old; on the other hand, old ones, red when brought into the house, lose their beautiful colors at the first moulting, and remaining grey like the young ones, are no more than grey linnets.

This difference of color does not take place in the females, which are smaller than the males; the upper part of the body is grey, streaked with dusky-brown and yellowish-white, on the rump, with greyish-brown and reddish-white; these spots are more numerous on the breast; the wing coverts are a dusky-chestnut. The females are distinguished in the nest by the back being more grey than brown, and by the number of streaks on the breast, which resemble that of the lark; bird fanciers leave these in the nest and take only the males.

Linnets breed twice a-year, and lay each time from four to six bluish-white eggs, covered all over with flesh-colored and reddish-brown spots and stripes. The male birds may be recognised in the earlier stage of their growth by the white ring round the neck, and the white on the tail and wings. 


\section{HYBRIDITY.}

IT is common for a male linnet to pair with a hen Canary, and hybrids produced by this means are easily reared, and can scarcely be distinguished from other grey Cararies, either from their appearance or song.

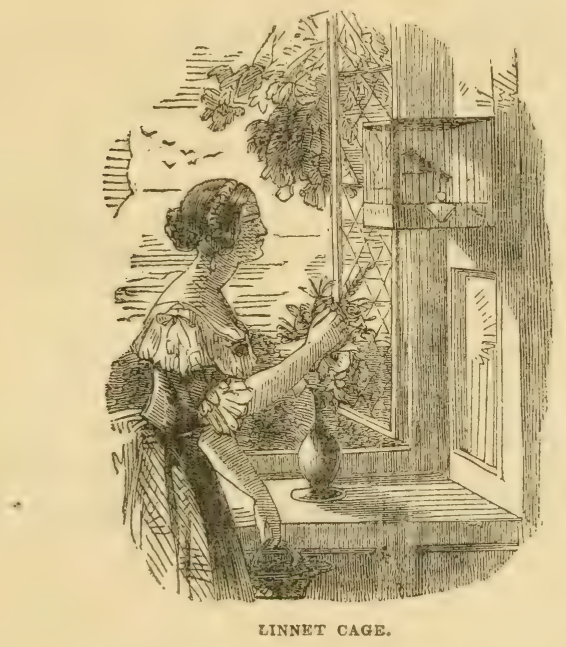

EOOD AND IVANAGEMENT.

IN confinement, linnets require nothing but summer cabbage seed,* which does not require to be soaked, as they are naturally seed-eating birds, having a powerful crop and stomach, and can therefore better digest it. Hemp seed, they must not have at all. They must not be too well fed in the cage; for, taking little exercise, they would soon die from over-feeding.

* Winter cabbage seed, which does not injure tinen at liberty, soon kills them in confinement. 
They like salt, and, contrary to the general rule, it is therefore well occasionally to intermix sone with their food; and this is an excellent preventive against various maladies. When linnets are allowed to rum about, they readily feed with other birds on the universal paste. Some grecn food must occasionally be given them, as also sand and water, as they like to bathe and dust themselves.

It is best to keep them in square cages, as they are less subject to giddiness in these than in round ones, and sing better. They are not often allowed to range the room, as they are very indolent, remaining immovable in the same place, and running the risk of being trodden upon; but if a small tree or a roost be placed in a corner, they may be let out of the cage with safety, as they will remain perched there, only leaving it to eat or drink, and will sing all day long.

\section{DISEASES:}

The most common disorders of this species are constipation, atrophy, and epilepsy; but linnets in confinement will gencrally live from twelve to sixtcen years.

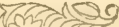




\section{THE AMERICAN GOLDFINCH.}

\section{Synonymes.}

\author{
Fringilla tristis, \\ Chardonneret jaune, \\ Amerikanischer Distelfink, \\ Jilguero americano, \\ Pintacilgo americano, \\ Calderino americano, \\ Yellow Bird, American \\ Goldfinch,
}

OF ORnithologists.

Of the French.

OF the Germans.

Of the Spaniards.

Ce the Portuguese.

Of the Italians.

$\{$ OF THE Britisil aNd

Anglo-Americans.

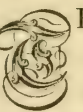

HIS very beautiful and familiar messenger of spring is known throughout this continent from the 49th parallel of north latitude to the savannas of Guiana and Surinam. As summer approaches, the males cast off their olivecolored winter suits, and appear in their temporary golden livery, with the front of the head, wings, and tail of a deep black, when they may be heard in concert, tuning their lively notes, several sitting on the same tree enjoying the exhilerating scene, basking and pluming themselves, and vying with each other in pouring forth their varied, soft, and cheerful song. When they sing all together, as they now do, it has a pleasing effect; their favorite note resembles the word băbée, or măy bé, the last syllable protracted and much higher than the first. They have also a note, which they utter when flying through the air, that sounds somewhat like the word physician, pronounced very rapidly. But the most bcautiful part of their song, is, when they raise and sink their voices in such a delight- 
ful cadence, that their music, at times, seems "to float on the distant breeze, scarcely louder than the hum of bees;" it then breaks out, as it were, into a crescendo, which rends the air like the loud song of the Canary.

In confinement, the yellow bird soon becomes familiar and reconciled, its song being nearly as animated and sonorous as its transatlantic congener. According to Mr. Audubon, it is extremely hardy, often remaining the whole winter in the Middle States, and when deprived of liberty, will live to a great age in a room or cage. "I have known two instances," says he, "in which a bird of this species had been confined for" upwards of ten years. They were procured in the market of New York, when in mature plumage, and had been caught in trap cages. One of them having undergone the severe training, more frequently inflicted in Europe than America, and known in France by the name of galerien, would draw water for its drink from a glass, it having a little chain attached to a narrow belt of soft leather fastened round its body, and another equally light chain fastened to a little bucket, kept by its weight in the water, until the little fellow raised it up with its bill, placed a foot upon it, and pulled again at the chain until it reached the desired fluid and drank, when, on letting go, the bucket immediately fell into the glass below. In the same manner, it was obliged to draw towards its bill a little charriot filled with seeds; and in this distressing, occupation was doomed to toil through a life of solitary grief, separated from its companions, wantoning on the wild flowers, and procuring their food in the manner in which nature had taught them."

The food of the American goldfinch consists chiefly of the seeds of the various species of thistles, lettuce, hemp, and sunflower; and in winter, when its more agreeable food is not found in sufficient abundance, it resorts to the fruit and seeds of the elder. It also collects the tender buds of trees, as well as the confervas of brooks and springs, as a variety of its usual fare.

These birds occasionally do some damage to gardens by their indis -iminate destruction of lettuce and flower seeds, 
and they are therefare often disliked by gardeners; but their usefulness, in other respects, far more than counterbalances the trifling injuries tl.ey produce.

After being caught in trap cages, they feed as if quite contented; but, should it happen to be in the spring that they lose their liberty, and have thus been deprived of the pleasures anticipated from the previous union of a mate, they linger for a few days, pine away, and die. They are very fond of washing and bathing themselves, in clear shallow water, when the weather is mild, aftcr which, they are engaged in picking up particles of sand and gravel, from which the fancier may take a useful hint.

It is stated that it is more difficult to procure a mule, or hybrid, between this species and the Canary, than between the latter and the European goldfinch, although the cross has often been made with success. 


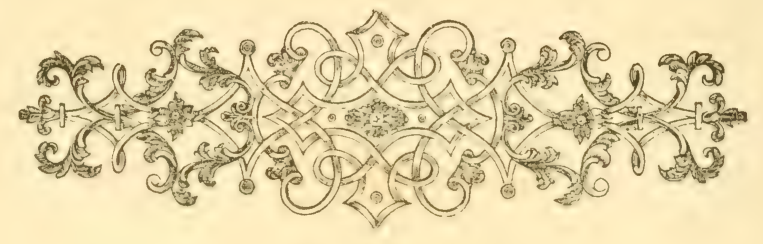

THE AMERICAN ROBIN.

Synonymes.

Turdus migratorius,

Tourd emigrant, Grieve du ? Canadi.

Auswanderer Drossel,

Tordo migratorio,

Tordo emigrante,

Tordo migrante,

American Robin, Robin Red- ? $\left.\begin{array}{l}\text { breast, Migrating Thrush, } \\ \text { Red-breasted Thrush, }\end{array}\right\}$
Of Ornitiologists.

Of the French.

Of tile Germans.

OF THE SPANIARds.

OF the Portuguese.

OF THE Italians.

$\{$ OF THE BRITISH AND

$\{$ ANGLO-AMERICANS.

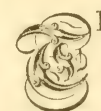

HE Amcrican robin is a saucy familiar bird, fond of man's neighborhood, throughout North America, from the 56th parallel of north latitude to the table lands of Mexico, and is more frequently to be seen in our orchards and fields than in the denser woods. The confidence he reposes in us by taking up his abode in our vicinage; the frankness and innocence of his mamners; the simplicity of his thrilling lays, delivered in all the artless energy of true love; and the peculiar pleasure with which we listen to his rocal powers, ever inspires us with attachment and universal respect. Besides, the endearing name he sometimes bears, recalls to mind 
the well-known legend, so oft repeated in our juvenile days, of the "favorite Robin Redbreast," said to have covered with a leafy shroud the lost and wandering "babes in the wood." He is commonly called "robin," though there is but little resemblance between him and his European congener, except in the single circumstance of his having a red breast.

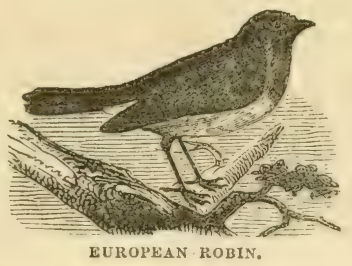

The American robin, when reared in a cage, is of a lively and gentle disposition, docile, and seemingly content, and the melody and simplicity of his song, of which he is very lavish in confinement, renders him a special favorite. He sings well, readily learns to imitate lively parts of airs, and on the authority of Mr. Nuttall, some have been taught to pipe forth psalms even to so solemn a measure as that of "Old Hundred !" He also acquires a considerable capacity for mimickry, imitating the notes of many of the birds around him, as those of the pe-wee, biue bird, and whip-poor-will. At times, he becomes very tame, and will go in and out of the house with domestic confidence, appear uneasy when left alone, and will follow his owner, come to her call, peck at her finger, or kiss her mouth, with seeming pleasure. His principal song, both in confinement and at large, commences in the morning before sunrise, and at which time it is very loud, emphatic, and full.

The rufous color of the breast becomes deeper in those birds brought up in confinement, and the females are somewhat paler than the males. The young, during the first season, are spotted on the breast with dusk and white. 
EOOD AND IVANAGEMENT.

DURING the winter, arcording to Mr. Audubon, the robin feeds on the berries and rruits of our woods, gardens, and fields, and even of the omamental trees of our cities and larger towns. The holly, sweet gum, gallberry, and the poke are those it first attacks; but as these fail, it feeds on the mountain ash, Carolinian cherry, and the azedarach. On the latter, in their annual migrations to Florida and the Southern States, these birds often glilt themselves to such an inordinate desree, that they are sometimes found stupified by its narcotic power. In spring and summer, they devour worms and snails. They also pick up from the fields the seeds of maize.

In confinement, this bird feeds on bread soaked either in water or milk, and on most kinds of our native and edible fruits. Being equally fond of insects as when at liberty, he seizes on all that enter his cage, or come within his reach.

The robin is comparatively a hardy and long-lived bird, and instances are reported of its having been kep for nearly twenty years. It suffers much in moulting, even in a wild state, and when in captivity, it loses nearly all its feathers at once. In general, when due care is obscrved to cleanliness, it is freer from parasitic vermin than most other species.

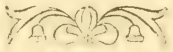




\section{THF SONG THRUSH.}

Synonymes.

\author{
Turdus musicus, \\ Grive, Tourd, \\ Singdrossel, \\ Tordo cantador, \\ Tordo, \\ Song Thrush,
}
Of ORnithologists.
Of the French.
Of the Germans.
SOF tile Spaniards
$\{$ and Portuguese.
Of the Italians.
$\{$ Of THE BRITISI AND
$\{$ Anglo-Americans.

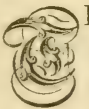

HE song thrush is one of the few birds whose clear and beautiful notes animates and makes pleasing the European woods. From the summits of the highest trees, it announces, by its varying song, resembling that of the nightingale, the approach of spring, and sings throughout the whole summer, especially in the morning dawn and evening twilight. For the sake of this song, it is kept by fanciers in a cage, whence evening and morning, even as early as February, it will delight a whole street by its loud and pleasing song, when hung outside of the window, or inside, so that the window be a little open. In Thuringia, it is reputed to articulate words. Its strophe was heard formerly more frequently than it is now. Only old and excellent birds still sing it. This thrush will live from six to eight years, if its food be varied. 


\section{DESCRIPTION.}

Tris species is eight inches and a half long, of which the tail occupies three inches and a half; the beak is nine lines long, horny-brown beneath, and from the middle to the base, yellow; the irides nut-brown; the feet pale lead-color, one inch high; the whole of the upper part of the body olivebrown; the throat whitish-ycllow, with a black stripe extending down its sides; the sides of the neck and breast, pale reddish-yellow, with numerous dark-brown, heart-shaped spots; the abdomen white, with oval dark-brown spots; the inside corretis bright orange-yellow : the pinion fathers greybrown; the tail feathers the same.

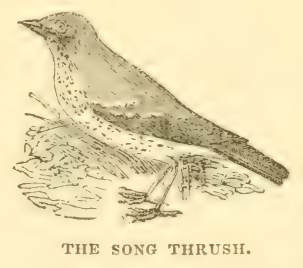

In the female, the two black lines of the throat consist of small stripes, and the breast is pale yellowish-white.

\section{FOOD AND MANAGENEENT.}

Tre food of the song thrush, in a state of liberty, consists generally of earth worms, but in autumn they eat berries of all kinds. Earth worms constitute their chief sustenance, with which they also feed their young. They are easily fed in confinement, and the universal paste is an agreeable delicacy to them. Barley meal, or merely wheat bran, wetted with water is sufficient to nourish them. But to get them into a state fit for song, they must have a more generous diet, such as roll, 
bread, meat, and many other things which come to table, for they are not dainty. They are fond of bathing.

In confinement, this bird is usually placed within a trellis, or it is put into a large cage of any shape, but at least three feet and a half long, and nearly as high; for, being a large and wild bird, and in constant motion, it easily injures its plumage. It is best that such large birds should have a separate room appropriated to them, as their copious excrements smell offensively.

\section{DISEASES.}

THE most usual maladies to which this bird is subject are a stoppage of the feather glands, constipation, ond atrephy. 


\section{THE MOCKING BIRD.}

\section{Synonymes.}

\author{
Turdus polyglottus, \\ Polyglotte, Tourd poly- ? \\ glotte, Grand Noqueur, \\ Vielzüngler Vogel, \\ Tordo poligloto, \\ Tordo polyglotto, \\ Tordo poliglotto, \\ Mocking Bircl,
}

\author{
OF ORNTHOZOGISTS. \\ Of THE French. \\ Of tile Germans. \\ Of the Spaniards. \\ Of the Portuguese. \\ OF THE Italians. \\ SOF THE Britisil AND \\ \{ Anglo-Americans.
}

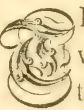

HIS "umivalled orpheus of the forest and natural wonder of Anericai." inhabits the whole continent from the state of Massichusetts along the Atlantic, including several of the West-India Tslands, as far south as Brazil; and from the table linds of liexico, along the very buse of the Rocky Mountains to Oregen, and the western sources of the river Platte. In short, he appear's to dwell permanently in the milder regions of the New World, in either hemisphere; and these bred north of the Delaware, on this side of the equator, are all that crer migrate, in autumn, to more congenial climes.

The mocking bird, though destitute of brilliant plumage, is delicate and symmetrical in his proportions and beautiful in his form. His motions are easy, rapid, and graceful, perpetually animated with a playful caprice, and a look that appears full of shrewdness and intelligence. He listens with silent attention to each passing sound, treasures up lessons 
from anything rocal, and is capable of imitating with exactness, both in measure and aceent, the notes of all the feathered race. And, however wild and discordant the tones and calls may be, he contrives with an Orphean talent, peculiarly his own, to infuse into them that sweetness of expression, and harmonious modulation which characterises this inimitable and wonderfnl composer. With the dawn of morning, while yet the sun lingers below the blushing horizon, our sublime songster, in his native wilds, mounted on the topmost branch of a tall tree or bush, pours out his admirable song, which, amidst the multitude of notes from all the warbling host, still rises pre-eminent, so that his solo is heard alone, and all the rest of the musical choir appear employed as mere accompaniments to this grand actor in the sublime opera of nature. $\mathrm{Nor}$ is his talent confined to imitation; his native notes are also bold, full, and perpetually raried, consisting of short expressions of a few variable syllables, interspersed with imitations, and uttered with great emphasis and volubility, sometimes for half an hour at a time, with undiminished ardor. 'These native strains bear a considerable resemblance to those of the brown thrush, with which he is so nearly related in form, habits, and manners; but like him, rude from cultivated genius, his notes are distinguished by the rapidity of their delivery, their variety, sweetness, and energy. As if conscious of his unrivalled powers of song, and animated by the harmony of his own voice, his music is, as it were, accompanied by chromatic dancing and expressive gestures; he spreads and closes his light, fanning wings, expands his silvered tail, and, with buoyant gaiety and enthusiastic ecstacy, sweeps around, and mounts and descends into the air from his lofty spray, as his song swells to loudness, or, in sinking whispers, dies away. While thus engaged, so varied is his talent, that it might be supposed a trial of skill from all the assembled songsters of the air ; and so perfect are his imitations, that even the sportsman is at times deceived, and sent in quest of birds that have no existence around. The feathered tribes themselves are decoyed by the fancied call of their mates; or dive with fear 
into the close thicket, at the well-feigned scream of the hawk.

Soon reconciled to the usurping fancy of man, the mocking bird often becomes familiar with his master; playfully attacks him through the bars of his cage, or at large in a room; restless and capricious, he seems to try every expedient of a lively imagination, that may conduce to his amusement. Nothing escapes his discerning and intelligent eye nor faithful ear. He whistles, perhaps, for the dog, who, deceived, runs to meet his master; the cries of the chicken in distress bring out the clucking mother to the protection of her brood. The barking of the dog, the piteous wailing of the puppy, the mewing of the cat, the action of a saw, or the creaking of a wheelbarrow quickly follow with exactness. He repeats a tune of considerable length; imitates the warbling of the Canary, the lisping of the indigo bird, and the mellow whistle of the cardinal, in a manner so superior to the originals, that, mortified and astonished, they withdraw from his presence, or listen in silence, as he continues in triumph.

In the cage, also, nearly as in the woods, he is full of life and action, while engaged in song; throwing himself round with inspiring animation, and, as it were, moving in time to the melody of his own accents. Even the hours of night, which consign nearly all other birds to silence and rest, like the nightingale, he oft cmploys in song, serenading the houseless hunter and silent cottager to repose, as the rising moon illumines the darkness of the shadowy scene. His capricious fondness for contrast and perpetual variety appcar's to deteriorate his powers. His lofty imitations of the musical brown thrush are perhaps interrupted by the crowing of the cock, or the barking of the dog; the plaintive warblings of the blue bird are then blended with the wild scream and chatter of the swallow, or the cackling of the hen; amid the simple lay of the native robin, we are surprised with the vociferations of the whip-poor-will ; while the notes of the garrulous jay, kildeer, woodpecker, Baltimore wren, and many others succeed, with such an appearance of reality, that we imagine ourselves 
in the presence of the originals, and can scarcely realise the fact, that the whole of this singular concert is the effort of a single bird. Indeed, it is impossible to listen to these Orphean strains, when delivered by a superior songster in his native woods, without being deeply affected, and almost rivetted to the spot, by the complicated feelings of wonder and delight, in which, from the graceful and sympathetic action, as well as enchanting voice of the performer, the eye is no less gratified than the ear.*

\section{DISTINCTION BETWEEN THE MALE AND FEMALE.}

THE young male bird, which must be selected as a singer, may be distinguished by the breadth and purity of the white on the wings. This white spot, in a full-grown male, spreads over the whole nine primaries, down to, and considerably below, their coverts, which are also white, sometimes slightly tipped with brown. The white of the primaries, also, extends to the same distance on both vanes of the feathers. In the female, the white is less clear, spreads only over seven or eight of the primaries, does not descend so far, and extends considerably further down on the broad than on the narrow side of the feathers. The black is also more inclined to brown.

\section{FOOD AND MANAGEMENT.}

In a state of freedom, the principal food of the mocking bird consists of insects, grasshoppers, and worms. Dewberries from the fields, and many kinds of our cultivated fruits, together with insects, supply the young as well as the parents with food. In winter, they chiefly subsist on berries, particularly those of the Virginia juniper, (red cedar,) wax myrtle, holly, smilax, sumach, sour gum, and a variety of others. 
Successful attempts have been made to breed these birds in confinement by allowing them retirement and a sufficiency of room. Those which have been taken in trap cages are accounted the best singers, as they come from the school of nature, and are taught their own wild wood notes. The young are easily reared by hand from the nest, from which they ought to be removed at eight or ten days old. Their food is thickened meal and water, or meal and milk, mixed occasionally with tender fresh meat, mineed fine. Animal food, almost alone, fincly divided and soaked in milk, is at first the only nutriment suited for raising these tender nurslings. Young and old require berries of various kinds, from time to time, such as cherrics, strawberries, whortleberries, \&c., and, in short, any kind of wild fruits of which they are fond, if not given too freely, are useful. $\Lambda$ few grasshoppers, beetles, or any insects conveniently to be had, as well as gravel, are also necessary; and spiders will often revive them when drooping or sick. But, notwithstanding all the care and management bestowed upon the improrement of this bird, it is painful to reflect that his extraordinary powers of nature, exercised with so much generous freedom in a state of confinement, are not calculated for long endurance; for, after this most wonderful and interesting prisoner has survived six or seven years, blindness often terminates his gay career-thus shut out from the checring light of heaven, the solace of his lonely, though active existence, he now, after a time, droops in silent sadness and dies. At times, this bird is so infested with a minute species of louse as to be destroyed by it.

Good singing birds of this species generally command from $\$ 5$ to $\$ 15$ each, though individuals of extraordinary and peculiar powers have been sold as high as $\$ 50$, or $\$ 100$, each, ane even $\$ 300$ have been refused! 


\section{THE BROWN THRUSH.}

\section{Synonymes.}

\author{
Turdus rufus, \\ Tourd roux, \\ Rother Drossel, \\ Tordo rojo, \\ Tordo ruç, \\ Tordo resso, \\ Brown Thrush, Ferruginous ? \\ Thrush, Thrasher, \\ French Mockirg Bird, \\ Red Mavy,
}

OF ORnithologists.

Of the French.

Of the Germans.

Of the Spantards.

Of the Portuguese.

OF The Italians.

( OF THE BRITISII AND

\{ Anglo-Americans.

OF the Southern States.

S OF Some Parts of New

\{ FNGLAND.

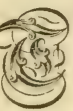

HIS large, cheerful, and familiar songster, inferior to none in musical talent, if we except the mocking bird, is found in almost every part of the United States from Canada to the shores of the Mexican Gulf, breeding, according to Mr. Nuttall, in all the intermediate space, though more abundantly towards the north. His voice somewhat resembles that of the European thrush, but is far more varied and powerful, rising pre-eminent amidst the forest choir. He takes no delight in mimicking the song of other birds, and therefore has no claim to the title of "mocking bird," as he is usually called at the south.

On the first appearance of this bird in the spring, he faulters in his song, like the nightingale, but when his mate commences the cares and labors incident to breeding and rearing her s young, his varied and melodious notes are steadily poured out 
in all their vigor and strength. In the month of May, while the blooming orchards perfume the air and decorate the landscape, his enchanting voice, in his affectionate lay, seems to give grateful utterance for the bounty and teeming profusion of nature, and falls in pleasing unison with the harmony and beauty of the season. And even the young birds, in a state of solitary domesticity, without the aid of their parent's voice, already whisper forth in harmonious reverie the pathetic and sweet warble instinctive to the species.

Deprived of other socicty, in a state of captivity, the brown thrush is exceedingly familiar, cheerful, and capriciously playful. He courts the attention of his keeper, follows his steps, complains when neglected, flies to him when permitted to be at large, and gratefully sings and reposes when perched on his hand. In short, in all his actions, he appears capable of real and affectionate attachment; but, like many other animals, he is jealous of every rival, particularly any other bird, which he drives from his presence with unceasing hatred.

\section{FOOD AND IMANAGEMENT.}

According to Audubon, the natural food of this species consists of insects, worms, berries, and fruits of all sorts, being particularly fond of ripe pears and figs. In winter, they resort to the berries of the sumach, holly, dogwood, and shrivelled wild grapes.

In a state of confinement, these birds may be reared in the same manner, and on the same kind of food as their congener, the mocking bird. In the autumn, of the first season, the young begin their musical studies, "repeating passages with as much zeal as ever did Paganini." By the following spring, their lessons are complete and the full powers of their song developed.

Like the American robin, the brown thrush suffers much in moulting, and often nearly loses all his feathers at once. 


\section{THE CAT BIRD.}

Synonymes.

\author{
Turdus felivox, \\ Gobe-mouche brun de Vir-? \\ ginie, Moucherolle de Vir-
ginie, Tourd miaulant, \\ Miauendrossel, \\ Tordo de maullido, \\ Tordo miante, \\ Tordo miagolare, \\ Cat Bird,
}

\author{
Of Ornithologists. \\ Of the French. \\ Of the Germans. \\ Of the Spaniards. \\ Of the Portuguese. \\ Or the ItaLians. \\ \{ OF THE BRITISI AND \\ Anglo-Americans.
}

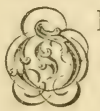

$\mathrm{NE}$ of the most remarkable propensities of this quaint and familiar songster, which inhabits almost every part of North America from Mexico to Canada, and even Kamtschatka, is the unpleasant, loud, gruting, and grimalkin-like mew, ('pāy,) that it often utters, on being offended or approached; and thus coupled with the name of a "wizzard animal," so much disliked by many, this delightful vocalist, which seeks out the very society of man, and reposes an Linmerited confidence in his protection, is generally treated with undeserved obloquy and contempt.

"The cat bird," says Nuttall, "often tunes his cheerful song before the break of day, hopping from bush to bush, with great agility, after his insect prey, while yet scarcely distinguishable amidst the dusky shadows of the dawn. The notes of different individuals vary considerably, so that sometimes his song, in sweetness and compass, is scarcely at all inferior to 
that of the ferruginous thrush. A quaintness, however, prevails in all his efforts, and his song is frequently made up of short and blended imitations of other birds, given however, with great emphasis, melody, and variety of tone; and, like the nightingale, invading the hours of repose, in the late twilight of a summer's evening, when scarce another note is heard but the hum of the drowsy beetle, his music attains its full effect, and often rises and falls with all the swell and studied cadence of finished harmony. During the heat of the day, or late in the morning, the variety of his song declines, or he pursues his cmployment in silence and retirement."

About the dawn of day, if at large, the cat bird flirts about with affected wildness, repeatedly jerks his wings and tail, with a noise somewhat resembling a whip, stretching forth his head, opens his mouth, and mews. Sometimes this curious cry is so guttural as to be uttered without opening his bill. He often also gives a squeal as he flies from one place to another.

According to Latham, this bird is also capable of imitating the variable airs of instrumental music, and will sometimes mimick the cry of chickens so as to deccive and distress the parent hen. When reared from the nest, he is easily domesticated, becomes a very amusing companion, and seems attached to his cage. Although a pleasant songster, he is seldom kept in confinement, and I believe all attempts at breeding it, have failed.

\section{FOOD AND MANAGEMENT.}

THE natural food of this species is similar to that of the ferruginous thrush, consisting principally of insects and worms, particularly beetles and wasps, and the various kinds of garden fruits.

In confinement, the food of these birds may be almost everything that is vegetable, except unbruised seeds, such as bread, fine pastry, containing little or no spices, cakes, 
scalded Indian meal, juicy fruits, and now and then some bread boiled in milk, a few insects, or minced flesh. The young, when taken from the nest, may be fed on ripe cherries, and other kinds of juicy fruits.

"Like all other thrushes," says Mr. Audubon, "this is very fond of bathing and rolling itself in the dust or sand of the roads and fields. Several are frequently seen together in the border's of small ponds or clear rivulets, immersed up to their body, splashing the water about them until completely wetted; then ascending to the top of the nearest bushes, they plume themselves with apparent care, notwithstanding which, they are at times so infested with a minute species of louse as to be destroyed by it." 


\section{THE EUROPEAN BLACKBIRD.}

\section{Synonymes.}

\author{
T'urdus merula, \\ Merle, \\ Schwarzdrossel, \\ Merlo, \\ Melro, \\ Blackbird, \\ English Blackbird,
}

\author{
Of Ornithologists. \\ OF THE F'RENCH. \\ Of the Germans. \\ ) OF the Spaniards \\ $\{$ and Italians. \\ Of the Pontuguese. \\ Of THE BRITISH. \\ Of the Anglo-Americans.
}

2) Horld, even as fitr north as Sweden, the

(0) European Blackbird is sufliciently hardy by nature to withstand the climate of nearly, if not all parts of the United States. Of all the thrushes, with perhaps the exception of the American robin, he is the most capable of instruction. His song is rich in melody, and contains some decp notes like those of the nightingale, varied, indeed, with some which are disagrecably harsh. At large, he sings only from March to July, especially at night; but in the cage, during the whole year except at moulting time. A single bird will enliven a whole street, so pure, distinct, and clear is his note. His memory, also, is so good, that he will learn several airs and melodies without mixing them; and sometimes even to imitate words. Neither does he forget what he has once well acquired. 


\section{DESCRIPTION.}

THE European blackbird is about the size of the song thrush, nine inches and a half long, of which the tail comprises four inches. The beak is one inch long, and of a golden-yellow; the irides dark-brown; the feet black, and fourteen lines high. The male is entirely of a deep-black; the female black-brown, rusty-colored on the breast, and with an ash-colored tinge upon the abdomen; the throat, spotted with light and darkbrown; the beak and the feet, black-brown, appearing also to be rather larger and heavier, and hence it has sometimes been considered a distinct species.

\section{FOOD AND IMANAGEMENT.}

WHEN wild, the blackbird, like other species of thrush, feeds on all kinds of edible berries, such as the elder, cherry, and mountain ash; and when this food is not abundant, it satisfies itself with the tips of the white thorn. At this time, it often secks for insects near the vicinity of warm springs.

In confinement, these birds are content with the first kind of universal paste, described at page 13, but will also eat bread, meat, and most kinds of food that comes to table. The young, which must be taken from the nest when their quills have but just sprung, can be reared upon roll steeped in milk.

The blackbird should be kept in a large cage, for it is not prudent to allow it to associate with other birds, as either through covetousness or caprice, it will attack the smaller kinds, and even peck them to death. Like all the allied species, this bird is fond of frequent bathing, and consequently should be amply supplied with the means. In captivity, he will live from twelve to fifteen years, especially if his food be varied. 


\section{DISEASES.}

THE blackbird is particularly subject to a stoppage of the oil gland, which may be softened by the application of fresh butter, mixed up with a good deal of sugar, the aperture being enlarged by gently distending it with a needle, or a small knife; but a lead salve, or rather a salve of litharge of silver, white lead, wax, and olive oil, which must be ordered at an apothecary's, opens it best. The usual remedy is to pierce it wich a needle, or to cut off the hardened gland. If this evil have not yet too severely affected the health of the bird, it may be sought to be remedied by puncturing the gland, compressing it frequently, bathing the bird with a syringe, and plucking out some of the feathers of the tail. The accumulated fat is absorbed in the renewal of the feathers, when the gland resumes its natural functions. 


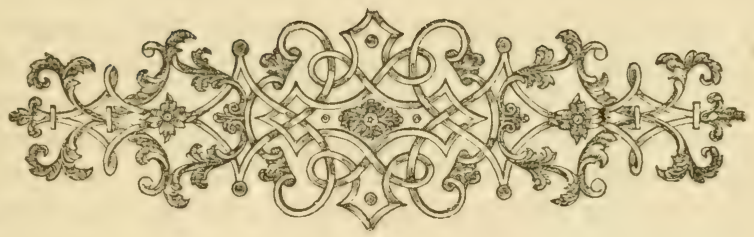

THE RICE BUNTING.

\section{Synonymes.}

Icicrus agripennìs, Emberiza oryzivora, Ortolan agripenne, Ortolan de riz,

Reiss Ortolan, Fettammer von Carolina,

Hortelano de arroz, Hortelano con $\}$ plumas agrias,

Cenchramo d'arroz, Cenchramo com? pennas agudas,

Ortolano di riso,

Rice Bunting, Rice Troopial, Rice Bird, ) Reed Bird, Boblink, Bob-o-link, Bob Lincoln, Bob Linkling, Skunk Blackbird, Meadow Bird, Butter Bird,
OF ORNITHOLOGISTS.

Of the French.

Of the Germans.

Of the Spaniards.

Of the Portuguese.

OF THE ITALTANS.

SOF THE Britis! AND A ANGLO-AMERICANS.

$\Rightarrow$ HIS well-known and truly migratory bird, familiarly Tfor known to everybody by the name of "Bob Lincoln," 1 who, as a stranger, perhaps, thinks it a point of politeness thus to announce himself, as he sits on a rail of the fence, or the branch of a tree, on his annual return in the spring from the south, inhabits the whole continent of America, from Labrador to Mexico; although his winter residence appears to be more confined to Cuba, Jamaica, and other West-India Islands than to the main. 
In the molith of May, these birds fix their abodes in the "savannahs" of Ohio and Michigan, and the cool grassy "meadows" of New York, Canada, and New Englarid for the purpose, principally, for hatching and rearing their young. The song of the male continues, with but little interruption, during the period of incubation, and his chant, at all times very similar, is both singular and pleasant. "Often, like the skylark, mounted and hovering on the wing, at a small height above the field, as he passes along from ore tree top or weed to another, he utters such a jingling melody of short variable notes, so confused, rapid, and continuous, that it appear's almost like the blending song of several different birds. Many of these tones are very agreeable, but they are delivered with such rapidity that the car can scarcely separate them. The general effect, however, like all the simple efforts of nature, is good, and when several are chanting forth in the same meadow, the concert is very checrful, though monotonous, and somewhat quaint. Among the few phrases that can be distinguished, the liquid sound of Bub-or-lee, or Bull-o-linhli, Bob-olinké, is very distinct.

"To give an idea of the sariable extent of song, and even an imitation, in some measure, of the chromatic period and air of this familiar and rather fitvorite resident, the boys of this part of New England, [Cambridge,] make him shout among others, the following ludicrous dumning phrase, as he rises and hovers on the wing near his mate:- 'B'Böb-ŏ-link, 'Bǒb-ŏ-link, 'Tŏm Denmy, 'Töm Denny-Come păy me the hür-ănd-six-pence you've ouced more than a year änd ă half cgo!-_'tshé 'tshe 'tshé, 'tsh 'tsh 'tske', modestly diving at the same instant down into the grass, as if to avoid altercation. However pucrile this odd phrase may appear, it is quite anusing to find how near it approaches to the time, and expression of the notes, when pronounced in a hurried manner." *

This relish for song and merriment, confined wholly to the male, diminishes as the period of incubation adrances, and when the young brood begin to flutter aroumd theip parrits, 
the song becomes less fieqent. Sometimes the female is inclined to have a second brood, for which preparation is made while she is yet engaged in rearing the first; but the male generally loses his musical talent about the first week in July; from which time, or perhaps earlier, his spring or pied dress begins gradually to be laid aside for the more humble brownishblack and brownish-ycllow garb of the female, the whole, both old and young, then appearing nearly in the same songless livery, uttering only a chink of alarm when surprised.

When the voice of the male begins to fail, with the progress of the exhausting moult, he flits over the ficlds in a restless manner, and merely utters a broken 'bób'lee 'bób'lee, or with his songless mate, at length, a 'weet 'weet, b'leet b'leet, or a noisy and disagreeable cackling chirp. But at the early dawn of day, while the tuneful talent of the species is yet unabated, the effect of their awakening and faultering voices, jingling throughout the wide expanse of meadows is singular and grand. These sounds mingle like the noise of a distant torrent, which alternately subsides and rises on the breeze, as the performers awake or relapse into rest; finally, they become more distinct and tumultuous, till, with the opening day, they assume the intelligible character of their ordinary song:

From the varied and changing plumage of this pleasing, and in some respects ludicrous bird, as well as for the singularity of his song, he is eagerly sought after by fanciers, and usually commands a fair price. Large numbers are annually captured in the Northen States in trap cages and fed, almost immediately after which, they resume their song. Many are purchased and carried to Europe, often to the disappointment of the adventurer, in regard to his profits, as, by the time they reach their destination, they change their livery and ccase to sing.

\section{FOOD AND MANAGEMIENT.}

THe food of the rice buntings varies according to the season and locality in which they reside. Although on their early arrival at the north it consists of grubs, worms, caterpillars, 
beetles, grasshoppers, crickets, ground spiders, \&c., they frequently feed on the seeds of dandelions and dockis, the former of which are oily and sweet. Later in the scason, and previous to leaving their native regions, they feed principally on various kinds of grass seeds, pariculirly those of millet or other allicel species (Panicums). If shurt of other food, they also attuck the ripened fields of barley, wheat, and oats, in which they show their taste for plunder, and flock together like other blackbirds.

About the middle of August, vast parties of these birds enter the states of New York and Pennsylvania on their way south, where, along the margins of the large rivers, they find an abundant means of subsistence, during their short stay, on the sceds of wild rice (Zizania). As soon as the cool nights of October set in, and the wild rice crops begin to fail, these birds take their departure from New Jersey and Pennsylvania, and in their further progress through the Southern States, they congregate in large numbers in the rice fields, upon which they grecdily feed, and, before the crop is gathered, they have alpeady made their appcarance in Cuba and Jamaica, where they subsist on the sceds of the Guinea griss, (Sorghum,) and become so fiat as truly to desrres the name of "butter birds," and are highly esteemed for the table.

In a state of captivity, the food of this hird, during spring and summer, should resemble as nearly as possible that of nature; but in winter, he may be fed on rice, boiled in milk, millet, Canary seeds, wheaten bread, soaked in water, and minced animal food, containing no seasoning nor salt. 


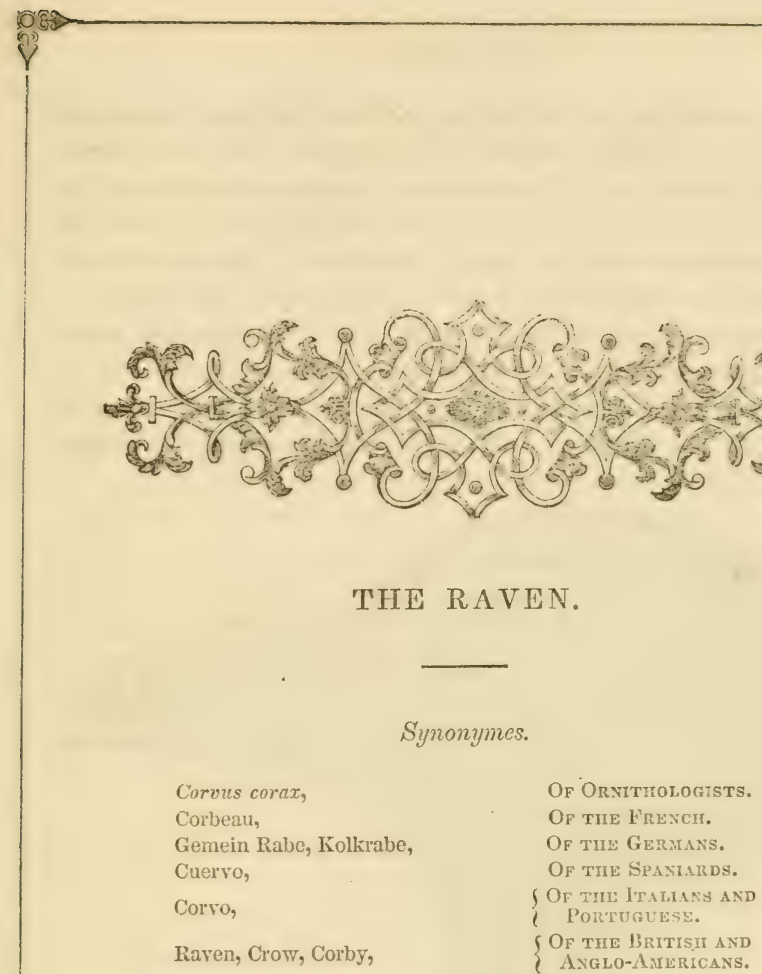

(c) $F$ all birds which have a convex, round, knife-shaped (Gily) bill, furnished at the base with hair projecting for(12) wards, in other words, of all that belong to the tribe of crows, this, from the breadth of its tongue, is the most easily taught to imitate the human voice. On the ground, he walks in a stately manner, his motions exhibiting a kind of thoughtful consideration almost amounting to gravity. His ordinary voice consists of a hoarse croak, resembling the syllable crŏck or crick; but he frequently emits a note not unlike the sound of a sudden gulp, or the syllable clück, which he seems to uiter when in a sportive mood; for, although ordinarily grave, the raven sometimes indulges in a frolic, performing somersets 
and various evolutions in the air. When divination formed a portion of the popular belief in Europe, this bird was held in considerable repute. Trouble was even taken to study its actions and all the circumstances attending its fiight, and the various modulations of its voice. Of these, sixty-four different variations were enumerated, without including the more delicate intonations, exceclingly difficult to distinguish, to detect which, however, an excessively fine car was requisite, as its cry, crǒck and crŭck, is so simple! Every distinct change had its peculiar signification, and there were not wanting people

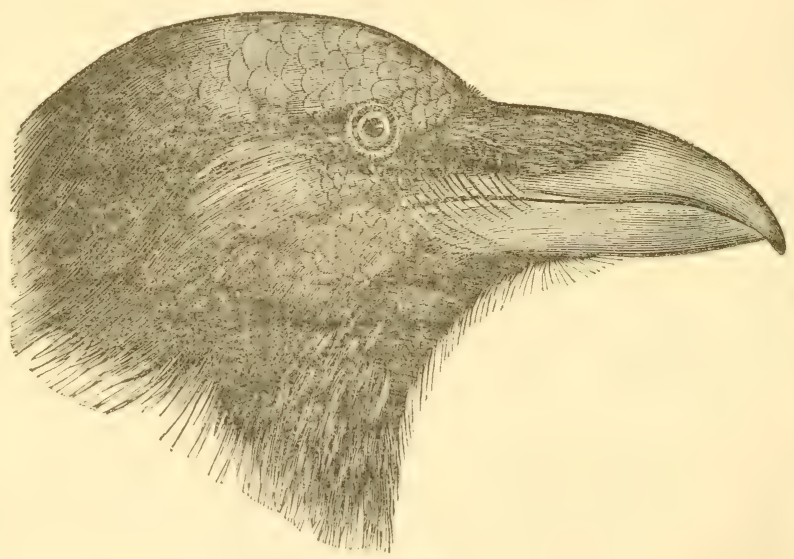

THE RAVEN.

who studied to acquire this knowledge, while others carried their folly so far as to believe that, by cating the heart and viscera of this bird, they could acquire its prophetic powers.

The raven may be said to possess a social disposition; for, after the brecding season has passed, flocks are often seen in the northern parts of Europe and the adjacent islands, amounting to one or more hundreds. These birds can perceive an object, as a dead carcass, at a great distance, but that they can smell carrion a quarter of a mile off, we have no satisfactory 
proof, neither need we believe that they can; for as we may accomnt for the phenomenon by their sight, it is umecesiary to have recourse to their other faculties. Ravens have charater in their flight, as men have in their wall. A poct satutering by a river, a conchologist or fisherman hunting along the shore for shells, a sportsman searching the woods and fielảs for game, a lady rumning home from a shower, or a gentleman retrcating from a mad bull, move each in a different manner, suiting the action to the occasion. In like manner, ravens, as well as other birds, might communicate intelligence, perhaps, several milc's distant, judging by the flight of their neighbors, that they had a prize in view. In this way, a system of telegraphing could be extended over a large extent of country, and a great number of birds might be made to assemble in a single day.

When domesticated and treated with kindness, the European raven, as well as our native variety, becomes attached to his owner, and will follow him about the gateden or house, with all the familiarity of a confiding friend.

\section{EOOD AND IMANAGEMENT.}

Althougr the raven is omnivorous, its chief food is carrion, by which is here meant the carcases of sheep, horses, cattle, deer, and other quadrupeds, dolphins and cetaceous animals in general, as well as fishes that have been cast ashore. In autumn, it sornetimes commits great havoc among graiis, and in spring, it occosionally destroys young lombs. It has also been accused of killing diseased sheep by picking out their eyes; but of this there is no satisfactory cvidence. It anmoys the housewives sometimes by flying off with young poultry, and especially by breaking and sucking eggs which the ducks or hens may have deposited, as they frequently do, among the herbage.

When these birds are intended to fiy about, the young must be removed when half fledged, about twelve days after they 
are hatched, and fed upon meat, snails, and earth worms; they are also accustomed to eat bread and roll steeped in milk. The description of food they seck, when at large, as young hares, birds, eggs, mice, young geese, chickens, snails, pears, cherrics, \&c., renders them partly injurious and partly beneficial.

This bird can be allowed to run at large, or fly about, and if reared from the nest, which must be the case if he is to be taught to speak, he will return to the place of feeding, upon calling him Jack, the name he usually bears. All glittering metal, especially gold, must be hidden fiom him, or he, like some other bipeds, will carry it off. To facilitate his speaking, or to give his tongue greater freedom, which is necessary for articulate somds, the tongue chord is sometimes loosened with the view of increasing or heightening his powers of speech. Individuals, however, have been heard to speak with an unloosened tongue. The raven is naturally a long-lived bird, indiriduals having been known to live upwards of one hundred years. 


\section{PIGEONS.}

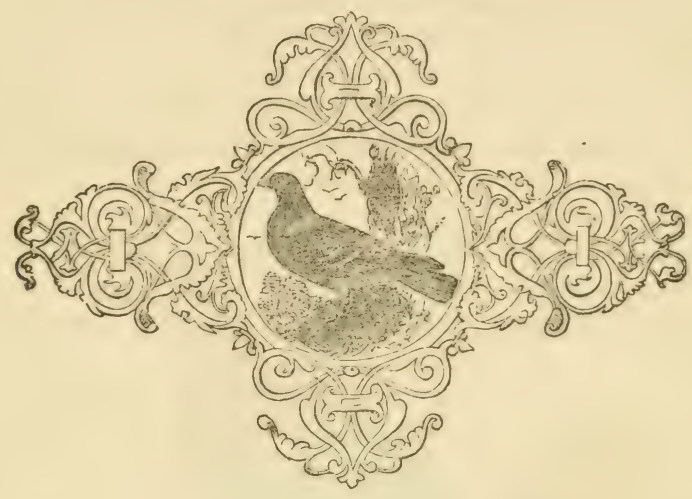

THE ROCK PISEON, OR WILD DOVE.

\section{Synonymes.}

Columba livia,

Colombe, Biset sauvage,

Holztaube,

Paloma toreaz, Paloma del \} campo,

Pombo bravo,

Colombo salvatico,

Biset, Wild Rock Pigeon,

White-Rumped Pigeon,

Rock Dove, Wild Dove,
OF ORNithologists.

Of the Frencit.

OF THE Germans.

Of the Spaniatis.

Of the Portuguese.

OF THE ITALIANS.

$\{$ OF THE BRITISI AND

$\{$ Anglo-Americans. A 3 the inhabitant of the pigeon houses in various parts of the world, or "dove cots," as they are more frequently call-il, buildings exprests crected for the purpose of containing colonies of these birds. In this state, where they enjoy a is perfert fredmon of acian, and are nearly dependant upon the ip 
own cxertions for support, they can scarcely be called "reclaimed," much less "domesticated." Man, indeed, has only taken advantage of certain habits peculiar to the species, and by the substitution of an artificial for a real cavern, (their natural habitation,) to which the pigeon house may be compared, has brought it into a kind of voluntary subjection, without violating, or at least greatly infringing upon its natural condition, and has rendered it subservient to his benefit and use.

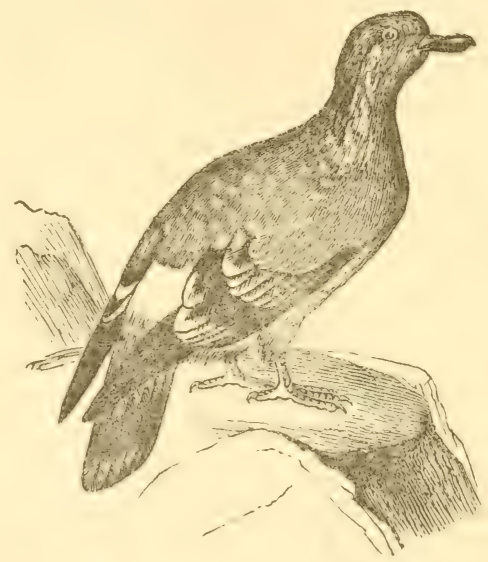

DESCRIPTION.

In its natural state, the bill of this bird is blackish-brown; the nostril membrane red, sprinkled, as it were, with a white powder; the irides, pale reddish-orange; the head and throat, bluish-grey; the sides of the neck and upper part of the breast are dark lavender-purple, glossed with shades of green and purplish-red ; the lower part of the breast, abdomen, wing curcrts, as well as the upper mandible, bluish-grey, the greater A corerts and seccndaries are barred with blick, forming two 
broad and distinct bars across the closec wings ; the lower part of the back is white; the rump and tail coveris; bluish-grey ; the tail, deep-grey, with a broad black bar at the end; the leses ind fect are purplish-red; the wings, when closcd, reach within half an inch of the end of the tail.

\section{ORIGEN OF FANCY PIGEONS AND THE COMIMON HOUSE DOVE.}

IT is from the wild rock pigeon, (C. livia,) that all those numerous varieties, or, as they are frequently termed, "races," of the common inhabitants of the dove cot have descended, which are so highly prized, and fostered with such care and attention by the fancier, or amateur brecder; for, however diversified their forms, colors, or peculiarity of habit may be, thoy are all considered as having originated from a few accidental varieties of the common house pigeon, and not from any cross of that bird with other species, no signs nor marks whatever of such being apparent in any variety known to us. In fact, the greater part of them owe their existence to the interference and art of man; for, by separating from the wild rock pigeon, such accidental varieties as have occasionally occurred, by subjecting them to captivity and familiarisation, and by assorting and pairing them together, as fancy or caprice suggested, he has, at intervals, generated all the various races, and peculiar casts, which, it is well known, when once produced, may be perpetuated for an indefinite period, by being kept separate from, and unmixed with, others ; or, in other words, what is commonly termed breeding "in-and-in."

Indeed, the fact, that all the varieties, however much they may differ in color, size, or other particulars, if permitted, breed freely and indiscriminately with each other, and produce a progeny equally prolific, is another and a convincing proof of their common and self-same origin; for it is one of those A universal laws of nature, which, if once sct asile or not 
enforecd, would plunge all animated matter into indescribable confusion, that the offspring preduced by the intercourse of different, (that is, distinct species, is incapable of further increase. That such an intercourse may be efiected, is well known; but it is generally under peculiar or artificial circumstances, and rarely when the animals, birds, or whatever they may be, are in their natural state, and in a condition to make their own election. Thus it is in the crosses obtained in a state of confinement, between the Cinary and goldfinch, linnet, \&zc. But in all these instances, the progeny are invariably "mules," and as a general rule, are incapable of further production; for although they may exhibit the passions natural to the sexes, and the fornales may produce egors, which, in seneral, even with extreme care, are found addled and incapable of being hatched. Such, I may add, is the case with hylorids of some of the erosses themselves; for the mongrel progeny of the wild turte dove, ('urtur communis,) of Europe, with the turtle of the aviary, ( T: risiria, has been proved, by frequent experinents, to he burren, although the two species whence it originated appear to be closely allied, and a mixed breed is casily procured; and such $\mathbf{l}$ im justified in saying, would be the event, if a cross could be obtained between the rock pigeon, (Culumbu litia.) and the European wood pigeon, (C. cnas, or stock dove, as it is improperly ealled, or with the ring pigeon, (C. palumbus, ) or any other species.

\section{VARIETIES.}

To describe or particularise all the varieties possessed by fanciers, would require a volume in itself; as, in addition to the permanent races, or those which, when liept pure, transmit their likeness to their offspring, there are intermediate casts produced by particular crosses between individuals belonging to the different varietics, and which, though highly prized in the first generation, are not considered worthy of further extension; as their progeny cammot be depended upon, but are 
found to degenerate, and are liable to run into still more distant and less-valued races.

Among the numcrous rarieties lept in aviaries by funciers, which are deemed worthy of being perpetuated by breding distinct, the following are held in particuliur esteen :-

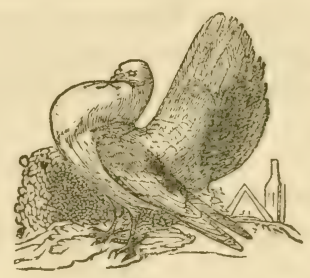

THE BROAD OR FAN-TAILED SHAKER.

This beautiful variety of the pigeon tribe reecires the name of "fan-tail," from its habit of spreading out the feathers of its tail like a turkey cock, (for the same reason it is called Pigeon paon by the French,) and that of "broad-tailed shaker" from its breadth of tail, and a peculiar quivering motion of the neck, which is regarded as the attitude of courtship. From this motion, it is also sometimes called by the French Pigcon trembleur paon.

This bird has a full breast, and a short, handsomely-formed, arched neck, which it carries in a graceful swan-like curve. Its tail, according to the rules of the fancy, should consist, at the least, of twenty-four feathers; and at the most, of thirty-six, which number it should not exceed; for, if the tail be overcrowded with feathers, the bird suffers it to droop, a defect nerer orerlooked, although the specimen may be faultless in every other respect.

Fan-tails, whose plumage is pure white, are more highly prized than those displaying red, yellow, blue, and black-pied colors; their carriage of the neck and tail being considered by fur the most striking and elegant. 
Some persons discriminate a variety which they call the "narrow-tailed shaker;" but this is only a degenerate breed of the fan-tail, or the result of a cross. Its neck is shorter and thicker, back longer, and it has not so many tail feathers as the broad-tailed shaker; neither does it expand its tail so fully, but keeps the feathers rather closed one over the other, so as to resemble a fan when some little way open. The color of its plumage is generally white; but a few different tints, and even an almond variety, are to be met with occasionally.

\section{TUMBLERS.}

These pretty pigeons are so called from their peculiar habit of tumbling backwards in the air when on the wing; besides which, they soar to so great a height as to be alınost lost to the view; when flying, they congregate very closely together; and if they be good birds and accustomed to each other, they will maintain such a compact flight, that a dozen may almost be covered with a large handkerchief.

If the weather be warm and bright, they may be allowed to wing their acrial gambols for four or fire hours in succession; but care must be taken, that no other species of pigeon mix with them, for if they once become familiarised and fly with others, they will gradually drop their highly-prized mode of flight, and of course become worthless. They should never be let out on a dull, heavy, misty morning, nor when a fog appear's to be rising, nor during a high wind; as all such atmospheric variations, by causing desertions rom their lofts tend to diminish the stock. A hen tumbler should never be allowed to fly while with egg.

The most esteemed tumblers do not somerset when swooping along, but only when they are beginning to rise, or when coming down to pitch; and to preserve this, and the high-flying properties in his stock, the provident fancier must spare no expence in the purchase of one or two first-rate birds that have been used to soaring, as they will be of much service in training the young ones. 
When the birds are accustomed to their houses, they may be turned out upon the wing, but only once a-day. A bright grey morning is the best time, especially for young birds; and some hemp or Canary sceds must be scattered round their cots, to entice them in, when their hours of liberty have expired.

There is a particularly fine variety of this pigeon, which is called the "bald-pated tumbler," denoted by the cut below, from its having a beautiful snowy white head; it has pearl eyes, and in plumage is exceedingly diversified; the tail and flight feathers, however, match the head, which is pure white. When a tumbler, either of a black or blue color, has a long dash of white from the under jaw and cheek to a little way down the throat, it is called a "black" or "blue-bearded" bird,

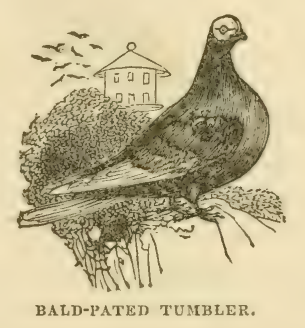

as the color may be; and if this beard be well shaped, and the bird be clean in the tail and flight, as before described, it may be reckoned very handsome and valuable. When these pigeons are dashing along in the brilliant sunshine, the lively contrast of their feathers adds much to the vivacity of their appearance.

There is another and still more beautiful variety of this breed, called by some funciers the "ermine tumbler," but which is generally known by the name of the "almond tumbler." It is an extremely elegant, and highly-prized variety, and is derived from common tumblers judiciously matched; as yellows, duns, whites, black-splashed, blackfrizzled, \&c., so as to sort the feathers. 
When in perfection, tumblers are esteemed by many persons to be the prettiest of all the pigeon tribe; and this high opinion is borne out by the beautiful diversity of their colors, which are so clegant and rich, in some birds, that they have been compared to a bed of tulips. The more they are variegated in the flight and tail, especially if the ground color be yellow, the more they are prized; and a fine bright-yellow ground has the precedence of all others, from its being so exceedingly difficult to aequire, that twenty light-colored birds inay be procured for one displaying a deep, richly-tinted ground.

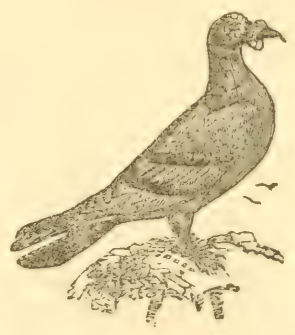

THE CARRIER.

The carrier, Pigeon de Turquie, of the French, is somewhat larger than most of the common pigeons; its feathers lie rery close and smooth, and its neck is long and straight. From the lower part of the head to the middle of the upper chap, there is a lump of white, naked, fungous-looking flesh, which is denoninated the "wattle;" this, in good birds, is met by two small swellings of similar flesh, which rise on each side of the uinder chay); and if this flesh be of blackish color, the bind is con!sidered very valuable. The cirele round the black pupil of the cye is usually of a brick-dust-red color; but if it be of at brilliant red tint, it adds considerably to the value of the bird; this circle is surrombed by another of naked fungons flesh, grenerally about the brealth of a half eagle, the greater the breadth of which, the more it is admired. When the incrusted 
flesh round the eye is very thick and broad, it shows that the pigeon will prove a good brecder, and will rear fine young ones.

The properties attributed to the carrier, and prized by fanciers, are three in the head, three in the eye, three in the wattle, and three in the beak. The properties of the head consist in its being flat, long, and straight; for instance, if the head be very long, narrow, and flat, it is reckoned, in shape, perfect; if the contrary, it is termed a "barrel head." The properties of the wattle of the eye are its breadth and circular, uniform shape; for, if one part appear to be more scanty than another, it is termed "pinch-eyed ;" and is of comparative little value; while, if it be full, even, and fiee from irregularities, it forms a "rose eye," and is highly prized. The wattle should be wide across the beak, short from the head to the point of the beak, and lean a little forward from the head; as the bird is said to be "peg-wattled" if it lie flat. The beak must be black, longs, straight, and thick; if it be an inch and a half in length, it is considered a long beak, but it must never measure less than an inch and a quiter; if the beak be crooked, (hookbeaked,) or spindle-beaked, the value of the bird is much diminished. This variety, in general, is either dun or black in color, although white, bluc-splashed, and pied specimens occur; the black and dun birds are usually the most perfect in their properties; but as the blues, whites, and pieds are very rare, even inferior birds of these colors are of considervalue.

THE HORSEMAN.

Many fanciers suppose the "horseman" to be a cross breed, either between a tumbler and a carrier, or a pouter and a carricr, and then again bred from a carrier. In shape, it resembles the carrier, but it is smaller in all its proportions; its body being less, its neck shorter and the fungous-looking flesh round its eyes not exuberant, so that there is a greater space between the wattle on the beak, than (s) that round the eye. 
'The most approved colors for this variety of pigeon are the blue, and bluc-pied, as they are usually the best brecders. They should be flown twice a-day regularly, when young; and as they gain strength on the wing, they should be allowed to

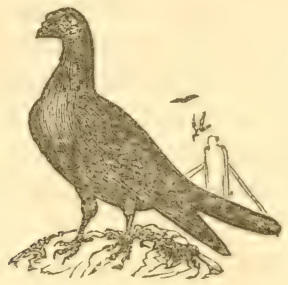

THE HORSEMAN.

range loose, without any other birds in company. This varicty is the kind generally employed in carrying letters; the genuine carriers being much too scarce and valuable to be commonly used.

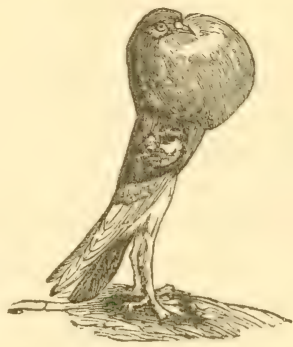

THE POUTER.

All pigeons, as is well known, have the capability of inflating their crops with air; and a fine pigeon, with breast feathers glossed with metallic tints, strutting and bowing, with an inflated crop, around his mate, presents no uninteresting spectacle; but this remark will not apply to this bird. In s the "English pouter," or " pouting horseman," there is nothing 
pleasing in its appearance nor graceful in its proportions; indeed, the intlition of the voluminous crop, rendering an erect, stiri, and aplatently constriined attitude necessary, gives an aspect of distsrtion, or a want of a due balance of parts.

The pouter is of large size, often measuring eighteen inches in lengih from the tip of the beak to the end of the tail. The chest is not really voluminous, though it appears enormous when the crop is distended with air; the back is concave, and the tail ample; the tarsi are very long, and covered with downy feathers. These pigeons are of various colors, as blue, rufous, pied, or altogether white. Those birds which are tall, erect, with a very ample crop, and with the colors of the plumage regularly disposed, and according to certain fancy rules, are esteemed the most valuable.

The pouter is formed by a cross between the "dragon" and the "old Dutch cropper," which latter bird, except in the development of the crop, (whence its name, had nothing to recommend it. From this intermixture, not without much care and expense, has resulted this fivorite variety. The flight of the pouter is buoyant, but not rapid, nor capable of being long sustained. As varietics of the pouter, or rather as breeds allied to it, may be mentioned the "uploper" and the "Purisian pouter," said to be a beautifully-marked bird; but with thesc, I have no personal acquaintance.

Pouters are very expensive birds to rear, as the strain will soon become degenerate. As the old birds pay little attention to the wants of their young, it frequently happens that the tiny creatures are starved to death. Carcful fanciers; throfore, never allow them to hatch their own eggs, but shift then as soon as they are deposited under a hen "dragoon," that has lately laid; and place the eggs of the latter bird under the pouter, in order that she may commence incubation; otherwise, she will lay again in a short time, which, often repeated, would, in all probability, kill her. Every pouter must ba kept by itself during the winter season; and their coops must be lofty, so that they my not acquire a stooping halnit, which is a very (c) great fau?t. In the spring, every pair of pouters must have 
two pair of dragoons to tend and feed them; but care must be taken that the dragoons are kept in a loft separate fiom the pouters, as otherwise, a cross breed would probably be the result, and the stock become degenerate.

Pouting horsemen are not so much in repute as formerly, the "almond tumblers" having almost superseded them.

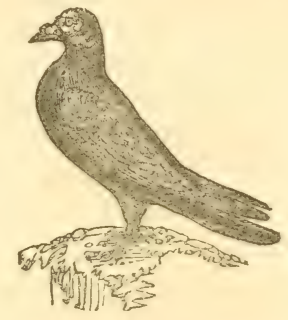

THE DRAGOON, OR DRAGON.

Dragons are bred between a itmbier and a horseman; and by frequently crossing thein with the horseman, they acquire much strength and swiftness. They aro exceedingly good brecders and kind nurses, and are, therefore, often lept as feeders for rearing young Leghom "l'unts," pouters, \&c.

The dragon is somewhat lighter and smaller than the horseman; and one of its chicf beautics consists in the straightness of the top of its skiull with that of its beak, which, according to the rules of the fancy, should form almost a horizontal line. These birds should be flown and trained while young, in the same way as the horsemen, which they are considered to surpass in swiftness, in short flights of from ten to twenty miles; but in longer distances, if the horsemen be well bred, they will far outstrip the dragoon.

THE JACOBIN.

This pigeon, often called a "Juck," is, when perfect in its properties, extremely rare. The real Jacobin is a very small bird, and the smaller it is, the more valuable; it has on the 
hinder part of its head, inclining towards the neck, a range of inverted feathers, in appearance like the cowl, or cap, of a monk; and from this peculiarity, it receives the sobriquet of "Jacobin," or "capper." These feathers are technically termed the "hood," and if they grow compact and close to the head, they culance the value of the bird considerably; the lower part of the hood is called the "chain," and the feathers composing it should be long and thick.

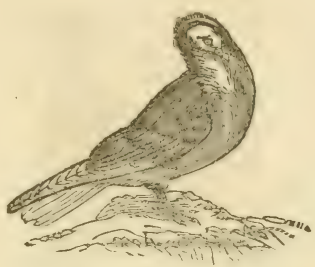

THE JACOBIN.

A small head, very smail spindle-shaped beak, and beautfully clean, pearl cyes are other properties of this little pet. Iellow, red, blue, and black are the colors usually bred, and in point of color, the yellow birds are preferred before all others; however, let the color of the body be what it may, according to the rules of the fancy, the tail, flight, and head must invariably be white; sometimes the legs and fect are covered with feathers.

THE CAPUCHIN.

In its properties, this varicty is closely allied to the Jacobin, and is, by some fancier's, considered a cross between that breed and some other kind. It has a longer beak, and is altogether a larger bird, than the Jacobin; its hood is extremely pretty, but it lacks the chain.

THE MAWMET.

The Mahomet, commonly corrupted to "Mawmet," is a beautiful cream-colored bird, with bar's of black across its wings; 
although the surface of its feathers is of a cream-color, the part next the body, the flue feathers, and even the skin, are of a dark sooty tint; it is about the size of a "turbit," but it has in place of a firill, a fine gullet, with a seam of beautiful feathers; its head is thick and short, and its eyes orange-color, surrounded by a small, naked circle of black flesh; it has a little black wattle on its beak, which is short and stout, and somewhat resembles that of a bulfinch.

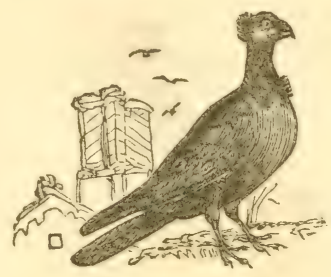

THE BARB.

This variety was originally brought from Barbary. In size, it is somewhat larger than the Jacobin; it has a short, thick beak, a small wattle, and a circle of thick, naked, incrusted flesh round its eyes; the wider this circle of flesh spreads round the eye, and the more brilliant its color, the more the bird is prized; the circle is narrow, at first, and is not fully developed until the bird is three or four years old.

The plunnage of the Barb is usually dun or biack; but there are pied birds of both colors; these last are held in little estimation, as they are supposed to be only half bred; when the pinion feathers are dark, the irides of its eyes are pearl color ; but when the pinions are white, the irides are red. Some of these birds are ornamented with a tuft of feathers rising from the back part of the crown of the head.

THE TURBIT.

This variety is somewhat larger than the Jacobin. Its head is round, and beak short; from the breast grows a tuft of feit- 
thers named the "purle," spreading in opposite directions, like the frill of a shirt; and from the beak to the purle reaches the gullet.

The colors of this pigeon are mostly yellow, dun, red, blue, and black; and accasionally chequered. According to the funcy, the back of the wings and tail should correspond in color, except in the yellow and red birds, whose tails should be white. A stripe of black should cross the wings of the blue birds, but the other body and flight feathers should be white; they are termed "black-shouldered," or "blue-shouldered," as their color may be; and when of one color only,

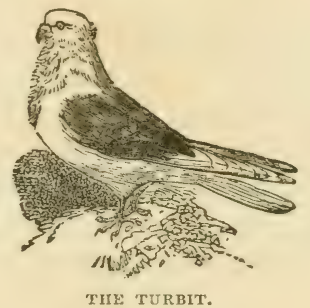

these pigeons have been sold a.s "owls." Turbits are also chosen for the shortness of their beaks, and their spreading "purle;" and if well-trained, when young, they will become excellent flyers.

\section{THE NUN.}

The nun is greatly admired, from the elegantly contrasting colors of its plumage. Its body is gene:ally white, and its tail and six flight feathers of its wings should be either wholly red, vivid yellow, or black, as likewise its head, which is adorned and nearly covered by a tuft, or "veil," of pure white feathers.

According to its colors, the bird is termed a red, yellow or black-headed "nun," as it may happen to be; and whenever the feathers vary from this rule, the bird is termed "foul-headed," or "foul-flighted," and is greatly diminished in value; but with such as frequently rear clean-feathered birds, as perfect 
sprecinens, it is scarcely pussible to obtain one entircly free from fou! fathers. Snallness of head and beak, a pearl eye, and largeness of veil, are desirable properties in this bird.

\section{THE HELMET.}

This varicty is a somewhat largor bird than the num. Its head, tail, and flight are mostly of one color, either yellow, blue, or black tint, and the other parts of the body are generally white; its head bears a delicate tuft of feathers, differing in color from the body, and in form like a helmet. It is a pretty bird, but is not a fine flyer. It is most useful as a nurse.

To the varietics already enumerated, I might add several other, as the "owl," the "ruff," the "spot," the "litee," the "fimmikin," and the "Friezland runt;" but these brecis wie not common, nor are they genemally held of much accrunt. As for the Fiench, Leghorn and the Spanish "rints," thoy are not to be placel among the fancy variotics, being remarkable merely for their size, and are appopriate for the dore cot.

FOOD.

In a state of nature, the rock dove feeds on grain and secds of various kinds, as well as on vegetables. Açcording to Misutagu, it also devours some kinds of snails, and is faricularly fond of the Helix virgata.

In a state of confinement or familiarisation, these birds are fond of almost erery kind of grain, but old tares are foumi, l,y (xperience, to l:e the best for them; horse beans, particrilarly the smalley surts, as small ticks, are considered next to tatres in point of nutritive properties; oats, barley, wheat, and peas, maty be given occisionally, and will be found wholesone varieties of dict. P'igeons are very fond of rape, hemp and Canary secds, which, however, should only be riren occasionally; and new tares should especially be given to yomng birds sery sparingly. Inany fincicrs make a composition of salt, 
lime mortar, and a little clay, mixed with spicy seeds, as caraway, which they allow thcir pigeons to feed upon at will.

The seed may be scattered on the floor amongst the gravel, although many persons recommend little contrivances to put it in, on the score of keeping it cleancr and better.

\section{DOIMESTIC ACCOMINODATION AND MANAGEMENT.}

Familiarised, or fancy pigeons are generally confined in aviaries, or lodged in appropriate buildings attached to or near the house of the breeder, in order that they may be regularly and easily fed, cleansed, and duly attended to in all matters having reference to their condition and health; for their natural instinct and feeling of liberty have been so nearly effaced, or placed in abeyance by the captivity to which they have been subjected, for so many generations, that they have become nearly dependent upon man for support, and have lost the power or capability, even when allowed to fly at large, of looking for and finding their own food.

In these buildings, it is common to erect a certain number of boxes, or divisions, against the walls or sides, each calculated to accommodate a pair of pigeons, with their nest and young. They succeed best when separate and distinct from each other, with a small platform, and an eutrance just large enough to admit the bird; as when disposed in a continuous row, and open in front, they are apt to interfere with each other, and, by their jealousies and contentions, prevent the due increase of eggs and young.

The most common shape for a pigeon house is the one represented in the succeeding illustration, but the form is immaterial. It is, however, necessary that the holes should be large enough for the birds to turn round in with ease; and there should be in front shelves and partitions of from seven to nine inches in depth, so as to keep the couples apart, and afford them resting places; and two holes for each couple, between each partition, will he desirable. The cot should be fixed where it will be 
screened from cold winds, which are extremeìy prejudicial to the birds; a southern or south-western aspect should, therefore, if possible, be chosen; visits from cats and rats must also be carefully guarded againsẗ.

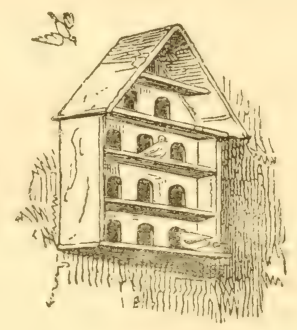

PIGEON HOUSY.

If the young fancier be enabled to fit up a loft over a stable, or other out-building, for a pigeon house, the best arrangement

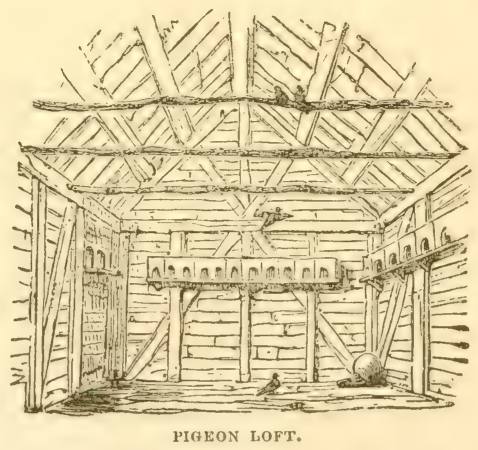

he can adopt is that shown in the above illustration. The means for exit and re-entrance must be first thought of ; and if there be no window in the loft, two holes must be made in the wall, at about five feet from the floor, each sufticicntly large to admit a pigeon easily; a shelf should be fastened on the inside, and another on the outside, of the said apertures; on 
this latter shelf, a trap, or "aërie," should be affixed, the intent and purposes of which I shall presently explain. At the upper part of the loft, rough branches should be placed as perches in the manner shown in the representation. At about four feet from the floor, breeding boxes, according to the number of birds intended to be kept, should be securely fixed to the wall, care being taken to protect them from rats, \&c.

Some fanciers furnish their boxes with little earthenware pans, or small baskets, for the birds to deposit their eggs in; although the eggs are not so likely to be broken in the baskets as in the pans, the latter, if supplied with straw, are cleaner than the baskets; the pans should vary in dimensions, according to the class of pigeon for which they are designed. It is well to put two of these receptacles in each little room, as the hens frequently go to the nest again when their broods are about three wecks old, leaving them to the care of their mates. Instead of ego boxes, shelves partitioned off, and having sliding fronts for the convenience of cleaning, are used; if the young fancier intend to keep "pouters," the shelves should be fourteen inches in breadth, and at least twenty inches apart, so that the birds may not acquire the habit of stooping, which depreciates their value.

As pigeons drink differently from most other birds, that is, by taking a long-continued draught, like cattle, a fountain, or large-bottomed glass bottle, with a tolerably long neck, for water, should be provided for their house; it should be placed on a small three-legged stool, so that its mouth may incline into an earthenware pan, into which the water will trickle slowly, and cease when it reaches the level of the mouth of the bottle, and a continued supply of fresh water thus be kept up; two or three bricks will serve instead of a stool, to give the bottle the necessary elevation.

To insure the thriving of the birds, the loft and shelves should be kept clcan, and gravel strown on the floor; indeed, gravel must on no account be omitted, as pigcons are exceedingly fond of pecking it.

The "aërie" before mentioned, which is fastened on the 
shelf outside of the loft, is a trap made of laths. It has two sides and a front only, the wall of the loft forming the back; the front and sides act upon hinges, so that they may be thrown

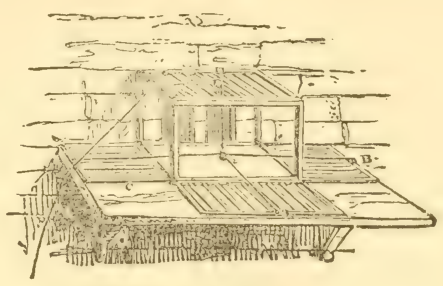

AERIE OPEN.

open, and laid flat on the platform, as in the above figure $A, B, C$; and on the upper parts of these flaps are fistened strings, united to a single string in the middle of the trap; the string is carried over the swivel $E$, at the top of the machine, to a hiding place, whence the owner can see all that passes, and when a bird alights within the aërie, he jerks the string, the flaps are elevated, and the bird is immediately a prisoner. The aërie, when shut, presents the appearance shown in the following illustration. This kind of trap is used not only by

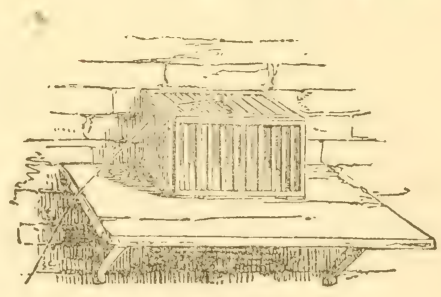

AERIE CLOSED.

funciers, but by amateurs; and i.; an important appendage to the loft, both as a incans of solf-defence to secure strays, and to shut in their own birds. Anong amateur fancicrs, the firstmontioned purpose is to sereure valuable and favorite breeds 
with them. When any strays are taken in the trap, they are killed for the table, unless called for and claimed by their owners, within twenty-four hours after their capture, and a tritling sum may then be domanded for trapparge.

To ensure the purity of any particular kind, the young males, as soon as they show symptoms of maturity, which may be known by particular gesticulations and their cooing notes, are placed apart in a chamber appropriated for the purpose, with a female of the sime variety. Inere they rinain till a mutual attachment his taken place, after which, they maty be returned to the gencral aviary, or dove house; for, when once an alliance is eirieted, it generally contimues undissolved and inviolate till the death or remoral of one of the parties; on which account many difierent varieties may be kept in the same aviary, or associuted together in one building, without much apprehension of having a contaminated breed.

For mating, or coupling pigeons, it is a good plan to build two cots, divided only by a lath partition, by which means the birds will sce each other, and may feed out of the same little vessels; when, by giving them plenty of hemp seed, they will soon be fit for mating. When the hen sweeps her tail, put her in the cock's pen, and they will readily agree. Where it is not convenient to make this probationary pen, and you are obliged to place them both in one coop, put the cock in a few days before his mate, that he may get accustomed to it, and fecl himself muster, especially if the hen be high spirited; else they will quarrel so ficrecly, that their disputes will terminate in a total dislike to one another.

When the pigeons are comfortably matched, allow them the full run of the loft, to select a nest for thenselves; or choose a nest for them, and inclose them in it for several days, by means of a slight lath railing, giving them an abundant supply of food and water during the whole time. Both male and female engage in the construction of the nest, and relieve each other in the task of incubation. Two erges only are laid, and the young are hatched blimb, naked, and helpless, and serlulously fed and cherished by both parents. Scveral pairs of young 
are reared during the season. The young are fed for some days after exclusion from the egs, not on grain, nor insects, but upon a peculiar lacteous secretion, or curd-like matter, which is poured out from a series of glands in the crop both of the male and female, which glands develope themselves into activity by a mysterious law at the proper juncture. This lactcous fluid is very abundant, and will frequently drip from the bills of the pigeons as they approach their young. It is thrown into the open mouths of the nestlings by a kind of exgurgitution, the receiving one and the giver being both in agitation. In the course of a few days, pulse or grain, moistened in the crops of the parents and mixed with this lacteous curdy fluid, is given, the secretion gradually decreasing as it is less and less required, till at length peas, moistened or macerated in the crop, are alone transferred into those of the young.

About the third day, some of the ordinary food, after maceration in the crop, is added, its proportion being increased, till at length, when the young quit the nest, it constitutes their food entirely.

Though fancy pigeons are kept for the sake of their beauty and peculiurities, the ordinary dove-house pigeon is reared almost exclusively for the sake of its flesh, which is accounted in most countries a delicacy. But how far the rearing of great numbers of these birds is profitable in our country may admit of question; the quantity of peas, beans, and grain, which eren a small flock will annually consume, is enormous. What, then, must be the consumption of flocks of many hundreds?

\section{DISEASES.}

Tue megrims, or epilepsy, is an incurable disorder, in which the pigeon mores about and flutters at random, with its head turned, and its bill resting upon its back.

If the birds sufier much while moulting, remove them to a 
warm place, mix a grood quantity of hemp seed in their ordinary food, and tinge their water with saffiron.

When the birds are affected with the wet roup, grive them a fi:w pepper corns once in three or four days, and put some green rue in their water.

'The dry roup is a husky cough, arising from a cold; when three or four cloves of garlic should be given to the birds daily.

When your pigeons are infested with insects, fumigate their feathers thoroughly with tobacco.

The canker is occasioned by the cocks pecking each other, which, as they are extremely irritable, they often do. To cure it, rub the part daily with a mixture of burnt alum and honey.

If the incrusted flesh round the eyes of "carriers," "Barbs," or "horsemen," be injured or pecked, bathe it with salt water; and if, in some days, this remedy does not succeed, another lotion composed of three drachms and a half of alum, dissolved in two ounces of water should be tried.

When "pouters" and "croppers" gorge themselves, by overeating, after long fasting, put the bird, feet downward, into a tight stocking, smoothing up the crop so that, overloaded as it is, it may be kept from hanging down; then hitch up the stocking on a nail, and keep the bird a prisoner until its food is digested, supplying it with a small quantity of water occasionally. When the bird is taken out of the stocking, it should be put into an open coop or basket, and fed but scantily for a while.

For lameness, or swelled balls of the feet, whether from cold, cuts with glass, or any accident, the most effectual application is a small quantity of Venice turpentine spread on a piece of brown paper.

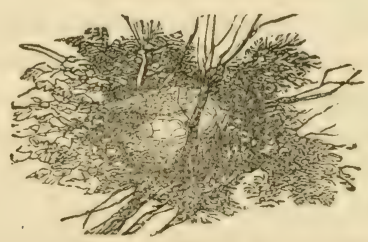




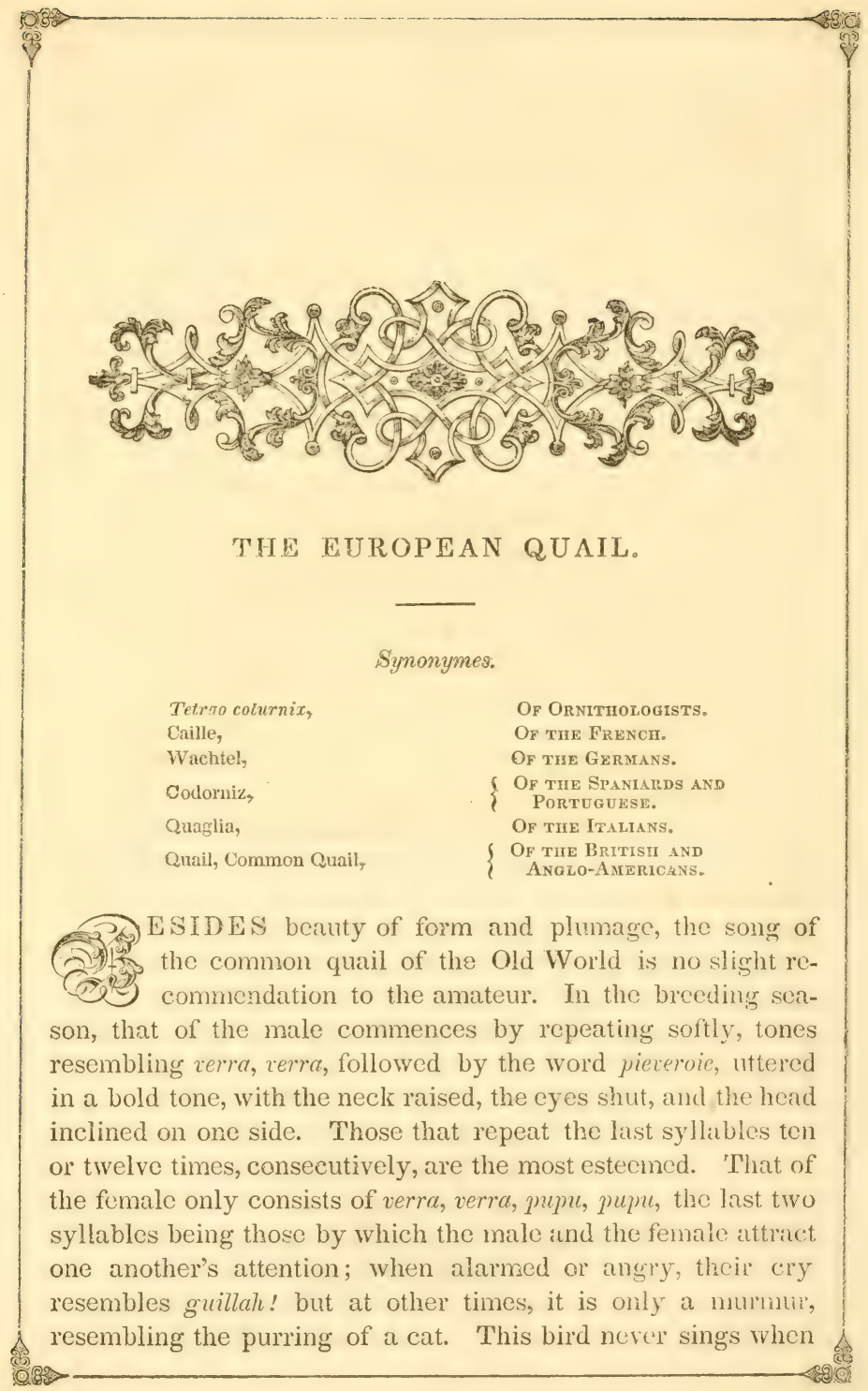


left to run about in a light romm, except during the night, but continually when in a darkened cage.

When wild, the qualil is found throughout the castern continent. It is a bird of passage, arriving in Europe in May, and taking its departure at the end of September.

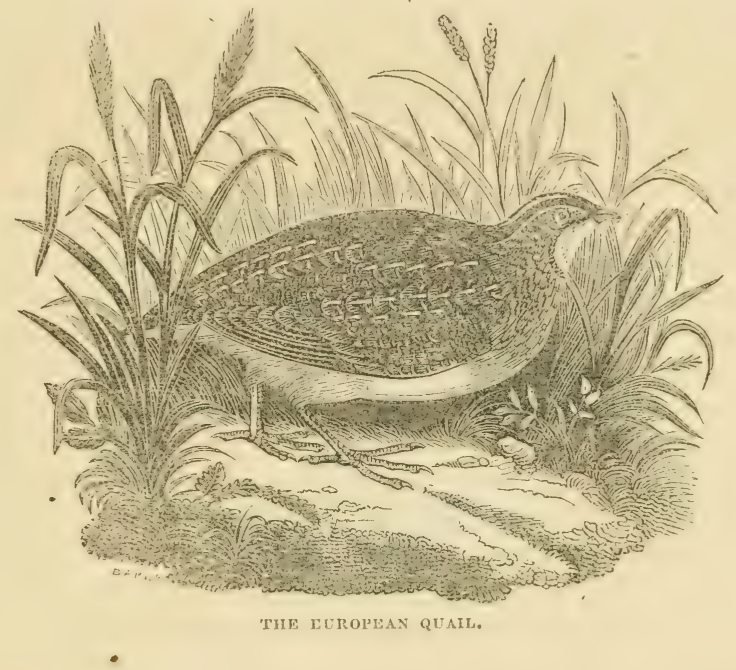

FOOD.

In a wild state, the quail feeds on wheat and other corn, rape seed, millet, hemp seed, and the like. It also eats green vegetibles, as well a.s insects, and particularly ants' eggs.

In the house, it is fed on the sime food, adding bread, barley meal, mixed with milk, the universal paste, and occasionally siliad or cabbage, chopped up small, and, that it may want nuthing to keep it in health, plenty of river sand for it to roll in and peck up grains, which assist its digestion; but this sand must be dimp, for if dry, it will not touch it. It drinks a is great deal, and the water, contritly to the opinion of some 
porsons, should be clear, and never turbid. It moults twice in the year, once in autumn, and again in spring; it then requires river sand, and greater attention than at other times.

\section{BREEDING.}

The quail brecds very late, never before July. Its nest, if it can be called so, is a hole scritched in the earth, in. which it lays firom ten to fourteen bluish-white eggs, with large brown spots. 'linese a:e hatehed after three weeks' incubation. The youmg ones, all hairy, fullow the mother the moment they leave the shell. Their teathers grow quickly, for in the autumn they are able to depart with her to the southern countries. The males are so ardent, that if one is placed in a room with a fimale, he will pursue her immediately with extraordinary eagerness, tearing oft her feathers if she resist in the least; he is less viulent if he has been in the same room with her during the year. The fomale, in this case, lays a great many eggs but rarely sits on them; yet if young ones are brought her from the fields, she cagerly receires them under her wings, and becomes a very aflectionate mother to then. 'The young must be fed on egge, boiled hard and cut small, but the best way is to take the mother with the covey, which may be done with a net. She watches over them attuntively, and they are more easily reared. During the first year, one would think that all in the covey were females, the males resemble them so much, particularly before the brown shows itself on the throat.

The adult female, however, differs very sensibly from the male; her throat is white, and her breast paler, and spotted with black, like that of the throat.

\section{MANAGEIMENT.}

In the house, if allowed to range, its gentleness, neatness, and peculiar motions are seen to advantage; but it is often kept in a cage of the following make:- 
A smail box, two feet long, one foot deep, and four high, of any shape which is preferred; in this are left two or three openings, one for drinking at, the other to give light; besides this all is dark; the bottom is a drawer, which should be covered with sand, and have a seed drawer at one end; the top is of green cloth; for as the quail often springs up it would hurt itself were it of wood. The case should be suspended during the summer outside the window, for the quail sings much more when confined in this mumner than if allowed to range the room, where there are many things to call off its attention frem its song. 


\section{$\mathbb{B R D S}, C A G E S, A \mathbb{D} S E D D S$.}

Tne Subscribers take this method of informing the public that they keep constantly on hand and for sale, from November to Nay of each year, a CHOICE COLLELTIUN OF IIEALTHY YOLNG BIRDS, noted for the excellenes of their song, fine forms, beautifully-marked plumage, and other good qualitles, consisting of ferman and French Cimaries, and other European sung Birds, thie prices of which vary according to their ages and qualities.

The prices of Canary Birds vary from $\$ 2$ to $\$ 10$ each, or $\$ 4$ to $\$ 15$ per pair.

\begin{tabular}{|c|c|}
\hline Goldfinches, ............................... \$2 to $\$ 2.50$ & 66 \\
\hline 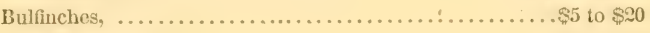 & 66 \\
\hline Song Thrushes, .......... & 6 \\
\hline Nigintingales, ............ & "6 \\
\hline Black Ciup.............. & " \\
\hline European Robins, ......................... $\$ 4$ to $\$ 8$ & 6 \\
\hline 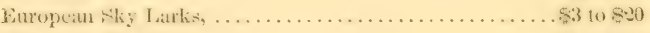 & $"$ \\
\hline European Wood Larks, ....................... $\$ 4$ to $\$ 10$ & 6 \\
\hline European Blackbirkt, ...................... to 510 & " \\
\hline 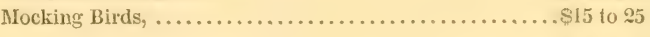 & "6 \\
\hline Breeding Cage: & " \\
\hline Gallery Cages ................... & 66 \\
\hline
\end{tabular}

Rape Seed, Millet, Cinary Seed, Metl Worms, Ltensils for Feeding, Materials for building nests, \&c., \&cc., on reasonable terms.

During the warmer montlis of the year, we visit Lurope for the purpose of replenishing our stock and making arrangements for subsequent importations.

All persons interested in this subject are respectfully invited to give us a call.

N.B. For change of place of business after the 1st of May, each year, seo adrenticement in the New-York Sun.

\section{CHARLES REICHE AND BROTHER,}

177 William street, New York. 







\section{$B 8$}

LIBRARY OF CONGRESS

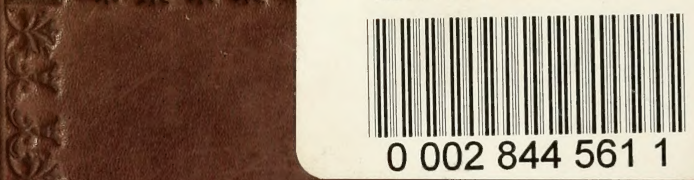

00028445611

ars

2034

(1).

2us

(cis

(1)

(a)

1)

The

(a)

W. 4

(3)

exs

5

(3)

(S)

(8).

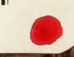

(8)

19

(10)

(1)

络被

(ais)

$+2$

2(s)

(1) 2$)$

4 ?

is

15.

$5(2)$

(4)

a

ty

(6)

1.

(1)

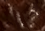

(19)

(3) की

is

군?

in

is

Q)

(3)

$(3)$

(a)

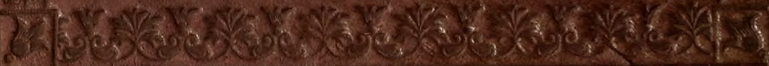

